\title{
Bathing effects of east saline groundwater concentrates on allergic (atopic) dermatitis-like skin lesions induced by 2,4 -dinitrochlorobenzene in hairless mice
}

\author{
CHOONG-GON KIM ${ }^{1 *}$, JI-EUN LEE ${ }^{2,3^{*}}$, DA-GEUM JEONG ${ }^{1}$, YOUN-HO LEE ${ }^{1}$, \\ SANG-IN PARK ${ }^{2,3}$, DAE-GEON LEE ${ }^{2,3}$, CHANG-HYUN HAN ${ }^{4}$, SU-JIN KANG ${ }^{2,5}$, \\ CHANG-HYUN SONG ${ }^{2,3}$, SEONG-HUN CHOI ${ }^{3}$, YOUNG-JOON LEE ${ }^{2,5}$ and SAE-KWANG KU ${ }^{2,3}$ \\ ${ }^{1}$ Biological Oceanography and Marine Biology Division, KIOST, Ansan, Gyeonggi 15627; \\ ${ }^{2}$ The Medical Research Center for Globalization of Herbal Medicine; ${ }^{3}$ Department of Anatomy and Histology, \\ College of Korean Medicine, Daegu Haany University, Gyeongsan, Gyeongsangbuk-do 38610; ${ }^{4}$ Department of Medical \\ History and Literature Group, Korea Institute of Oriental Medicine, Daejeon 34054; ${ }^{5}$ Department of Preventive Medicine, \\ College of Korean Medicine, Daegu Haany University, Gyeongsan, Gyeongsangbuk-do 38610, Republic of Korea
}

Received June 28, 2016; Accepted March 6, 2017

DOI: $10.3892 /$ etm.2017.4397

\begin{abstract}
In the present study, it was evaluated whether east saline groundwater concentration solution (ESGWc) exerted a favorable inhibitory effect on 2,4-dinitrochlorobenzene (DNCB)-induced allergic/atopic-like dermatitis (AD). AD was induced and boosted by sensitization with DNCB via topical application on the dorsal back skins. Mice with DNCB-induced AD were bathed in 100-, 200- and 400-fold diluted ESGWc. After 6 weeks bathing, changes to body weight, clinical skin severity scores, scratching behavior, serum total immunoglobulin (Ig)E levels, submandibular lymph node and spleen weights, splenic cytokine levels, skin cytokine mRNA expressions, antioxidant defense systems and superoxide anion productions were recorded to determine the effects of bathing on the histopathology of dorsal back skin tissues. All DNCB-induced mice demonstrated that the induction of AD through IgE-mediated hypersensitivities, oxidative stresses, activation of MMP and apoptosis of keratinocytes resulted in no significant differences in body weight between the different groups at each time point following initial sensitization.
\end{abstract}

Correspondence to: Professor Young-Joon Lee, Department of Preventive Medicine, College of Korean Medicine, Daegu Haany University, 1 Haanydae-ro, Gyeongsan, Gyeongsangbuk-do 38610, Republic of Korea

E-mail: gksxntk@dhu.ac.kr

Professor Sae-Kwang Ku, Department of Anatomy and Histology, College of Korean Medicine, Daegu Haany University, 1 Haanydae-ro, Gyeongsan, Gyeongsangbuk-do 38610, Republic of Korea

E-mail: gucci200@hanmail.net

"Contributed equally

Key words: groundwater concentrates, allergic/atopic-like dermatitis, apoptosis, antioxidant, anti-inflammatory, immunomodulatory effects
However, markers of DNCB-induced AD were significantly inhibited $(\mathrm{P}<0.05)$ in a concentration-dependent manner following bathing in all concentrations of ESGWc. The results obtained in the present study suggest that bathing in ESGWc may have favorable protective effects against DNCB-induced AD due to favorable systemic and local immunomodulatory effects, active cytoprotective anti-apoptotic effects, inhibitory effects of matrix metalloproteinase activity, and anti-inflammatory and antioxidative effects.

\section{Introduction}

Allergic/atopic dermatitis (AD) is characterized by various symptoms, including itching, erythema, eczema skin lesions, chronic relapse and pruritus (1). Patients with AD, may experience itchy skin, inducing scratching behavior and increasing the induction of pro-inflammatory cytokines $(1,2)$. This, in turn, triggers immune cells and activates an inflammatory cycle of allergic dermatitis that is accompanied by erythema, keratosis and scaling of the skin (2). Due to an imbalanced immune response to various allergens (3), there are a number of symptoms, such as erythema, keratosis and scaling, that occur during AD. Another characteristic of the allergic immune system is the ability to produce a greater number of immunoglobulin E (IgE) antibodies and type 2 helper T cells (Th2), which are pivotal for IgE synthesis $(4,5)$. Th2 cells predominantly induce the production of interleukin (IL) families and these cytokines are associated with the specific function of immune cells in $\mathrm{AD}(5) . \mathrm{IgE}$ is used as an indicator of AD severity and abnormalities of the skin barrier, a key feature of AD (6). During allergic inflammation, IgE and IgE-mediated mast cell and eosinophil activation contribute to AD $(4,5)$. In addition, $\operatorname{IgE}$ is able to sensitize mast cells in the skin when cell-bound IgE is cross-linked by allergens, culminating in the production of inflammatory mediators, such as interleukins (IL) $-4,-5$ and -13 and tumor necrosis factor (TNF)- $\alpha$ (5). The cytokines IL-4 and IL-13 released by mast cells contribute to 
the Th2 response (5). TNF- $\alpha$ produced by macrophages also serves an important role in the acute phase of AD (7) and it has been demonstrated that oxidative stress is involved in the pathogenesis of $\mathrm{AD}(3,8)$.

To relieve the symptoms of $\mathrm{AD}$, adrenocorticosteroids and anti-histamine agents have been utilized due to their ameliorating effects. However, they evoke severe side effects (9), therefore alternative therapies and natural products have been investigated for the treatment of $\operatorname{AD}(3,6)$. Hydrotherapy is regarded as a complementary therapy for AD in the therapeutic field (10). A number of studies have investigated the association between different water baths and their beneficial effects on dermatological disorders $(11,12)$. Different types of water have demonstrated unique and distinct characteristics, although each water type differs in composition (13). Hydrotherapy may regulate lymphocyte proliferation and cytokine production (13) due to the antioxidant effects of the mineral composition of different types of water $(14,15)$. Various seawaters exhibit protective effects against various types of dermatitis $(16,17)$. Notably, the present study is a follow-up to a previous study by the present authors, in which it was demonstrated that bathing in four different types of seawater collected around Korea induces favorable systemic and local immunomodulatory effects, active cytoprotective anti-apoptotic effects, inhibitory effects of matrix metalloproteinase (MMP) activity, anti-inflammatory and antioxidative effects against 2,4-dinitrochlorobenzene (DNCB)-induced AD (18). The four types of water included: West surface seawater (WSSW) collected around Wepo-ri, Ganghwa-do, Korea; west saline groundwater (WSGW) collected at Yonggungoncheon, Seokmo-do, Korea; east surface seawater (ESSW) collected around Nagok-ri, Uljin, Korea; and east saline groundwater (ESGW) collected around Hoojeong-ri, Uljin, Korea (18). The greatest protective effects were demonstrated by ESGW, followed by WSGW, ESSW and WSSW, respectively (18).

As ESGW demonstrated the most protective effect among the four different types of seawater collected around Korea (18), the objective of the present study was to evaluate the potential concentration-dependent inhibitory effect of three different dilutions (100-, 200- and 400-fold dilutions) of ESGW concentration solution (50X; ESGWc) on DNCB-induced AD-like skin lesions in hairless mice following 6 weeks of bathing (once daily for 42 days for $20 \mathrm{~min} /$ day). Bathing is regarded as a method of developing a novel alternative therapy for AD patients (10); in the present study, it was used to determine the inhibitory effect of ESGWc against DNCB-induced AD-like skin lesions. Results were compared with those of $1 \%$ dexamethasone (DEXA) topically applied to the mice (once a day for 42 days) as a control treatment (18). Among animal models, DNCB-stimulated mice exhibit diverse symptoms similar to those of AD, including skin infiltration of inflammatory cells and increases in mast cell numbers and serum IgE levels (19). Therefore, a hairless murine model of DNCB-induced AD was selected to identify the bathing effects of various types of seawaters.

\section{Materials and methods}

Animal model. A total of 110 6-week SKH-1 female hairless mice were obtained from Orient Bio, Ltd., (Seungnam, Korea; body weight ranged in 20 23 g upon receipt) and 6 groups (each, $n=8$ ) were selected 5 weeks following DNCB sensitization based on body weight (intact control: $27.51 \pm 1.07 \mathrm{~g}$; DNCB treated mice: $27.37 \pm 0.87 \mathrm{~g}$ ), clinical skin severity scores (intact control: $1.00 \pm 0.76$ scores; DNCB treated mice: $12.45 \pm 1.01$ scores) and scratching behavior (intact control: $11.88 \pm 5.46$ frequencies/30 min; DNCB treated mice: 478.93 \pm 94.64 frequencies/30 min). Animals were acclimatized for 10 days and placed in polycarbonate cages (4 mice/cage) in a temperature $\left(20-25^{\circ} \mathrm{C}\right)$ and humidity $(50-55 \%)$ controlled room. Mice were housed under a $12 \mathrm{~h}$ light/dark cycle and standard rodent chow (Samyang Corp., Seoul, Korea) and water were available ad libitum. All laboratory animals were treated according to the national regulations of the usage and welfare of laboratory animals, and approved by the Institutional Animal Care and Use Committee of Daegu Haany University (Gyeongsan, Korea; approval no. DHU2015-068). The mice were subdivided into six groups, comprising three control groups (intact, DNCB treatment for negative control and DEXA treatment for reference control) and three treatment groups (ESGWc 100-, 200- and 400-fold treatment).

Preparation of seawaters and DEXA. Colorless clear solutions of ESGWc were prepared by AriBio Inc. (Seoul, Korea). Briefly, ESGW was collected around Hoojeong-ri (Gyeongsang, Korea) and a 50-fold concentrated solution was created using a rotary evaporator (N-1200B; Tokyo Rikakikai Co., Ltd., Tokyo, Japan). In addition, appropriate amounts of Ca-lactate and $\mathrm{NaCl}$ were separately prepared to supplement for the reduction in minerals during the concentration process. Salinity and mineral compositions of ESGWc compared with ESGW and general underground water are listed in Table I. White powders of water-soluble DEXA (Sigma-Aldrich; Merck KGaA, Darmstadt, Germany) were obtained and used in the present study as a potent reference agent. All test materials used in the present experiment were stored at $4^{\circ} \mathrm{C}$ in a refrigerator to protect from light and humidity until usage.

Induction of $A D$. AD-like dermatitis was induced in mice by sensitization with $10 \mathrm{mg} / \mathrm{ml}$ DNCB (Sigma-Aldrich; Merck $\mathrm{KGaA}$; dissolved in a 3:1 mixture of acetone and olive oil) once a day for 1 week and boosted by $5 \mathrm{mg} / \mathrm{ml} \mathrm{DNCB}$ three times a week for 28 days, according to established previous methods $(3,18)$. DNCB solutions were topically applied on the dorsal back skins of mice in a volume of $200 \mu \mathrm{l} / \mathrm{mouse}$. In control mice, vehicle (3:1 mixtures of acetone and olive oil) was topically applied, instead of DNCB solution.

Bathing and topical application of DEXA. ESGWc 100-fold dilutions (2-fold dilutions of original ESGW) were selected as the highest concentrations based on a previous study investigating the effects of ESGW on DNCB hairless mice, in which favorable anti-AD effects were demonstrated at this concentration (18). In addition, 200- and 400-fold dilutions were selected as the middle and lowest concentrations, respectively, using common ratio 2. ESGWc were 100-, 200- and 400-fold diluted with distilled water, using 10, 5 and $2.5 \mathrm{ml} \mathrm{ESGWc}$ in 990, 995 and $997.5 \mathrm{ml}$ of distilled water, respectively. Appropriate amounts of Ca-lactate and $\mathrm{NaCl}$ were added to supplement for the reduction in minerals during the concentration process with a $\mathrm{Ca}: \mathrm{Mg}$ balance, salinity and conductance adjustment of 
Table I. Salinity and mineral compositions of different seawaters.

Mineral compositions, mg/l

\begin{tabular}{lcccrrrr}
\cline { 5 - 7 } Seawater & Salinity, & Conductance, $\mathrm{ms} / \mathrm{cm}$ & Balance, Ca:Mg & $\mathrm{Ca}$ & $\mathrm{Mg}$ & $\mathrm{K}$ & $\mathrm{Na}$ \\
\hline GUGW & - & - & $0.67: 1$ & 81.00 & 121.00 & 12.00 & 569.00 \\
ESGW & 24.20 & 38.02 & $1.80: 1$ & $1,720.00$ & 950.00 & 100.00 & $6,000.00$ \\
ESGWc & - & - & $1.19: 1$ & $53,707.00$ & $45,080.00$ & $2,800.00$ & $15,000.00$ \\
\hline
\end{tabular}

GUGW, general underground water; ESGW, east saline groundwater; ESGWc, east saline groundwater concentration solution (50X).

2.11 and 7.40, 1.06 and 3.70, 0.53 and $1.85 \mathrm{~g}$ in 100-, 200- and 400 -fold dilutions of ESGWc, respectively. All mice in the ESGWc groups were allowed to swim freely in the ESGWc in mouse polycarbonate cages $(200 \times 260 \times 130 \mathrm{~mm}$; DJ-101; Daejong Instrument Industry Co., Seoul, Korea), which contained $\sim 1,900 \mathrm{ml}$ of warm water at $\sim 37^{\circ} \mathrm{C}$ and bottom plates $4 \mathrm{~cm}$ deep, for $20 \mathrm{~min} /$ day.

DEXA treatment was performed as follows: Water-soluble DEXA was dissolved in distilled water to form a $1 \%$ solution and topically applied to the dorsal back skins (200 $\mu \mathrm{l} /$ mouse) once daily for 6 weeks, 5 weeks after initial DNCB sensitization. Intact and DNCB control mice bathed in distilled water instead of test waters in the present experiment to induce the same swimming stresses. Test waters and $1 \%$ DEXA solutions were warmed to $\sim 37^{\circ} \mathrm{C}$ at least $30 \mathrm{~min}$ prior to bathing to avoid cooling irritations. A total bathing period of 6 weeks was selected for the present study, based on previous findings of the bathing effects of mineral-rich water (20) and the results of a previous study into the bathing effects of various seawaters collected around Korea (18).

Changes in body weight. Changes in body weight were measured once a week, from 1 day prior to initial DNCB sensitization to the end of the 6-week bathing period in the three different concentrations of ESGWc, distilled water or topical application of $1 \%$ DEXA, using an automatic electronic balance (Precisa Gravimetrics AG, Dietikon, Switzerland). To reduce individual differences, the total body weight gains during the 11-week whole experimental period and the total body weight gains during the 6-week bathing or topical application of $1 \%$ DEXA period were calculated.

Evaluation of clinical skin severity scores. Five signs of skin lesions, including pruritus/itching, erythema/hemorrhage, edema, excoriation/erosion and scaling/dryness were graded as follows: 0, (no symptoms); 1, (mild); 2, (moderate); and 3, (severe). Total scores (maximum $=15$ ) were regarded as the clinical skin severity score, in accordance with previous reports $(3,18)$, with some modifications. Scoring was conducted once a week for 6 weeks, starting 5 weeks after DNCB sensitization and ending $24 \mathrm{~h}$ after the final bathing (11 weeks after DNCB sensitization). An additional scoring was conducted 3 days after initial bathing (38 days after initial DNCB sensitization).

Evaluation of scratching behavior. Each mouse from each group was placed individually in a routine polycarbonate mouse cage and their behavior was monitored for $30 \mathrm{~min}$ once a week, from 5 weeks after initial DNCB sensitization to $24 \mathrm{~h}$ after final bathing (11 weeks after first DNCB sensitization) including 3 days after initial bathing (38 days after first DNCB sensitization), respectively. Scratching of the rostral back and biting of the caudal back were observed; scratching movements by the hind paw were defined as a scratching bout that ended when the mouse either licked its hind paw or placed its hind paw back on the floor. A series of one or more biting movements was counted as one episode that ended when the mouse returned to the straight-forward position (3).

Serum total IgE level measurement. At 6 weeks after the initial bathing, $\sim 1 \mathrm{ml}$ venous blood was collected from the vena cava under anesthesia with 2 to $3 \%$ isoflurane (Hana Pharm Co., Ltd., Hwasung, Korea) and maintained with 1 to $1.5 \%$ isoflurane in a mixture of $70 \% \mathrm{~N}_{2} \mathrm{O}$ and $28.5 \% \mathrm{O}_{2}$, and serum was separated by centrifugation at $21,000 \mathrm{x} \mathrm{g}$ for $10 \mathrm{~min}$ at $4^{\circ} \mathrm{C}$ using a clotting-activated serum tube (BD Biosciences, San Jose, CA, USA). Total IgE levels in sera were determined by sandwich ELISA using the mouse IgE ELISA kit (cat. no. 555248, BD Biosciences), according to previous methods $(3,6,18)$. Briefly, plates were coated with capture antibody in ELISA coating buffer and incubated overnight at $4^{\circ} \mathrm{C}$. Subsequently, plates were washed with phosphate-buffered saline (PBS)-Tween-20 (0.05\%) and blocked with $10 \%$ fetal bovine serum (FBS; Gibco; Thermo Fisher Scientific, Inc., Waltham, MA, USA) in PBS for $1 \mathrm{~h}$ at $20^{\circ} \mathrm{C}$. Serial dilutions of standard antigen or sample in dilution buffer (10\% FBS in PBS) were added to the plates and plates were incubated for $2 \mathrm{~h}$ at $20^{\circ} \mathrm{C}$. Following three washes with PBS-Tween-20 (0.05\%), biotin-conjugated anti-mouse IgE and streptavidin-horseradish peroxidase conjugate were added to the plates, according to the ELISA kit protocols, and plates were incubated for $1 \mathrm{~h}$ at $20^{\circ} \mathrm{C}$. Finally, tetramethylbenzidine substrate solution was added to the plates and following 15-min incubation in the dark, a $2 \mathrm{~N}$ $\mathrm{H}_{2} \mathrm{SO}_{4}$ solution was added to stop the reaction. Optical densities were measured at $450 \mathrm{~nm}$ using an automated ELISA plate reader (Tecan Group, Ltd., Männedorf, Switzerland).

Lymphatic organ weight measurements. At $24 \mathrm{~h}$ after the end of the forty second bath, the mice were sacrified by exsanguination through vena cava under anesthesia with $3 \%$ isoflurane and dissected. The spleen and left submandibular lymph node (LN) in each mouse were collected following 
elimination of the surrounding connective tissues, muscles and debris. Individual weights of lymphatic organs were measured in grams to record absolute wet-weight. To reduce the individual body weight differences, the relative weight (\% of body weight) of lymphatic organs was calculated using body weight at sacrifice and absolute organ weight according to previously established methods (18).

Splenic cytokine content measurements. Splenic concentrations of TNF- $\alpha$, IL-1 $\beta$ and IL-10 were measured by ELISA using commercially available kits, including a mouse TNF- $\alpha$ ELISA kit (cat. no. 558534, BD Biosciences), a mouse IL-1 $\beta$ ELISA kit (cat. no. MBS824757) and a mouse IL-10 ELISA kit (cat. no. MBS8244590; both MyBioSource, Inc., San Diego, CA, USA), respectively, as previously described (18). Tissue samples (10-15 mg) were homogenized in a tissue grinder containing $1 \mathrm{ml}$ lysis buffer (PBS containing $2 \mathrm{mM}$ phenylmethylsulfonyl fluoride and $1 \mathrm{mg} / \mathrm{ml}$ aprotinin, leupeptin, and pepstatin A, all obtained from Sigma-Aldrich; Merck KGaA), as described by Clark et al (21). Analysis was performed with $100 \mathrm{ml}$ standard (diluted in lysis buffer) or 10, 50 or $100 \mathrm{ml}$ tissue homogenate. Each sample was run in duplicate and a portion of the sample was analyzed for protein. Data were expressed as $\mathrm{pg} / \mathrm{mg}$ of protein. For each assay, a standard curve was generated and based on replicates of the measured absorbance, demonstrated an average coefficient of variance of $<10 \%$.

Reverse transcription-quantitative polymerase chain reaction $(R T-q P C R)$. Total RNA was extracted from skin tissue samples using TRIzol ${ }^{\circledR}$ reagent (Invitrogen; Thermo Fisher Scientific, Inc.), according to a previously described method (18). cDNA was synthesized from $2 \mu \mathrm{g}$ total RNA in a final reaction volume of $20 \mu \mathrm{l}$. RNA was reverse transcribed using a High-Capacity cDNA Reverse Transcription kit (cat. no. 43-749-67; Applied Biosystems; Thermo Fisher Scientific, Inc.), according to the manufacturer's instructions. Briefly, a mixture of $2 \mu \mathrm{l}$ RT buffer, $0.8 \mu \mathrm{l}$ dNTP mix, $2 \mu \mathrm{l}$ RT primers, $1 \mu 1$ MultiScribe $^{\mathrm{TM}}$ reverse transcriptase, $1 \mu \mathrm{l}$ RNase inhibitor and $3.2 \mu \mathrm{l}$ nuclease-free distilled water was prepared and mixed with $10 \mu \mathrm{l}$ RNA sample. Reverse transcription was performed as follows: $25^{\circ} \mathrm{C}$ for $10 \mathrm{~min}, 37^{\circ} \mathrm{C}$ for $120 \mathrm{~min}, 85^{\circ} \mathrm{C}$ for $5 \mathrm{~min}$. RT-qPCR analysis was carried out with a CFX96 $6^{\mathrm{TM}}$ Real-Time System (Bio-Rad Laboratories, Inc., Hercules, CA, USA) using iTaq ${ }^{\mathrm{TM}}$ SYBR-Green (Bio-Rad Laboratories, Inc.). Nuclear free water, forward primer $(10 \mu \mathrm{M})$, reverse primer $(10 \mu \mathrm{M})$ and SYBR Green were mixed with cDNA in a $10 \mu \mathrm{l}$ reaction volume. The PCR cycling conditions included an initial pre-denaturation of $95^{\circ} \mathrm{C}$ for $1 \mathrm{~min}$, denaturation for $15 \mathrm{sec}$, annealing of $55-65^{\circ} \mathrm{C}$ for $20 \mathrm{sec}$, and extension of $72^{\circ} \mathrm{C}$ for $30 \mathrm{sec}$. A total of 50 cycles were performed. All reactions were done in triplicate. The expression of GAPDH mRNA was used as a control for tissue integrity in all samples. The sequences of the PCR oligonucleotide primers for TNF- $\alpha$, IL-4, IL-5, IL-13 and GAPDH are listed in Table II. For quantitative analysis, the intact control skin tissue was used as the control, and the relative expression of TNF- $\alpha$, IL-4, IL-5 and IL-13 was calculated using the $2^{-\Delta \Delta \mathrm{Cq}}$ method (22).

Glutathione (GSH) assay. Cutaneous GSH levels were determined using a fluorescence assay, as previously described (23).
Firstly, skin (1:3, w/w dilution) was homogenized in $100 \mathrm{mM}$ $\mathrm{NaH}_{2} \mathrm{PO}_{4}$ (pH 8.0; Sigma-Aldrich; Merck KGaA) containing $5 \mathrm{mM}$ EDTA (buffer 1). Homogenates were then treated with $30 \%$ trichloroacetic acid (Sigma-Aldrich; Merck KGaA) and centrifuged twice, at $1,940 \times \mathrm{g}$ for $6 \mathrm{~min}$ at $4^{\circ} \mathrm{C}$ and at $485 \mathrm{x} \mathrm{g}$ for $10 \mathrm{~min}$ at $4^{\circ} \mathrm{C}$ and the fluorescence of the resulting supernatant was measured using a fluorescence spectrophotometer (RF-5301PC; Shimadzu Corp., Kyoto, Japan). Briefly, $100 \mu \mathrm{l}$ supernatant was mixed with $1 \mathrm{ml}$ buffer 1 and $100 \mu \mathrm{l}$ o-phthalaldehyde (1 mg/ml in methanol; Sigma-Aldrich; Merck KGaA). Fluorescence was determined after 15 min $\left(\mathrm{k}_{\mathrm{exc}}=350 \mathrm{~nm} ; \mathrm{k}_{\mathrm{em}}=420 \mathrm{~nm}\right)$. The standard curve was prepared with various concentrations of GSH $(0.0-75.0 \mu \mathrm{M})$. Protein levels in the skin homogenates were measured using the method described in a study by Lowry et al (24). Results were presented as $\mu \mathrm{M} \mathrm{GSH} / \mathrm{mg}$ of protein.

Lipid peroxidation. Firstly, the protein content of homogenate $(10 \mathrm{mg} / \mathrm{ml}$ in $1.15 \% \mathrm{KCl})$ was measured using the method described by Lowry et al (24). The thiobarbituric acid reactive substances (TBARS) measurement was used to evaluate lipid peroxidation, as previously described (25). For this assay, 10\% trichloroacetic acid (Sigma-Aldrich; Merck $\mathrm{KGaA}$ ) was added to the homogenate to precipitate proteins. This mixture was then centrifuged for $3 \mathrm{~min}$ at $1,000 \mathrm{x} \mathrm{g}$ at $4^{\circ} \mathrm{C}$. The protein-free sample was extracted and $0.67 \%$ thiobarbituric acid (Sigma-Aldrich; Merck KGaA) was added. The mixture was kept in a water bath at $100^{\circ} \mathrm{C}$ for $15 \mathrm{~min}$. Levels of malondialdehyde (MDA), an intermediate product of lipoperoxidation, were determined by difference between absorbances at 535 and $572 \mathrm{~nm}$ on a microplate spectrophotometer reader (Tecan Group, Ltd., Männedorf, Switzerland) and the results were reported as $\mathrm{nM} / \mathrm{mg}$ of protein (18).

Superoxide anion production. The quantification of superoxide anion production in skin tissue homogenates $(10 \mathrm{mg} / \mathrm{ml}$ in $1.15 \% \mathrm{KCl}$; tissue was obtained after sacrifice) was performed using the nitroblue tetrazolium (NBT) assay, as previously described (26). Briefly, $50 \mu 1$ homogenate was incubated with $100 \mu$ l NBT ( $1 \mathrm{mg} / \mathrm{ml}$; Sigma-Aldrich; Merck KGaA) in 96-well plates at $37^{\circ} \mathrm{C}$ for $1 \mathrm{~h}$. Subsequently, the supernatant was carefully removed and the reduced formazan solubilized by adding $120 \mu 12 \mathrm{M} \mathrm{KOH}$ and $140 \mu \mathrm{l}$ dimethyl sulfoxide. NBT reduction was measured at $600 \mathrm{~nm}$ using a microplate spectrophotometer reader (Tecan Group, Ltd.). Protein content was used for data normalization.

Histopathology. Samples from dorsal back skins, spleen and left submandibular LN were separated and fixed in $10 \%$ neutral buffered formalin at room temperature for $24 \mathrm{~h}$, embedded in paraffin, sectioned into 3-4- $\mu \mathrm{m}$ sections and stained with hematoxylin and eosin (H\&E) for general histopathology, Masson's trichrome (MT) for collagen fiber or toluidine blue for mast cells, according to previously described methods (18). Following this, the histopathological profiles of each sample were observed under a light microscope (Eclipse 80i; Nikon Corporation, Tokyo, Japan). Mean epithelial thicknesses of the epidermis $(\mu \mathrm{m})$, mean numbers of inflammatory and mast cells infiltrated in the dermis (cells $/ \mathrm{mm}^{2}$ of dermis), total splenic thicknesses (mm/central regions), mean numbers of white pulp 
Table II. Oligonucleotides for reverse transcription-quantitative polymerase chain reaction.

\begin{tabular}{lllr}
\hline Target & Direction & \multicolumn{1}{c}{ Sequence (5'-3') } & Gene bank number \\
\hline Tumor necrosis factor- $\alpha$ & Forward & CCTGTAGCCCACGTCGTAGC & NM_013693.2 \\
Interleukin-4 & Reverse & 5TTGACCTCAGCGCTGAGTTG & NM_021283.2 \\
& Forward & GAATGTACCAGGAGCCATATC & NM_010558.1 \\
Interleukin-5 & Reverse & CTCAGTACTACGAGTAATCCA & TCACCGAGCTCTGTTGACAA \\
Interleukin-13 & Forward & CCACACTTCTCTTTTGGCG & NM_008355.3 \\
Glyceraldehyde & Reverse & GACCCAGAGGATATTGCATG & \\
3-phosphate dehydrogenase & Forward & CCAGCAAAGTCTGATGTGAG & NM_008084.2 \\
\hline
\end{tabular}

(white pulps $/ \mathrm{mm}^{2}$ of splenic parenchyma) and red pulp cells ( $\times 10^{3}$ cells $/ \mathrm{mm}^{2}$ of splenic parenchyma), total submandibular $\mathrm{LN}$ thicknesses ( $\mathrm{mm} /$ central regions), cortex lymphoid follicle numbers (follicles $/ \mathrm{mm}^{2}$ of cortex) and mean thicknesses $(\mu \mathrm{m} / \mathrm{LN})$ of submandibular $\mathrm{LN}$ were calculated for general histomorphometrical analysis using a computer-assisted image analysis program (iSolution FL v. 9.1; IMT i-solution Inc., Irvine, CA, USA) under H\&E stain and collagen fiber occupied regions in the dermis $\left(\% / \mathrm{mm}^{2}\right.$ of dermis) under an MT stain, according to previously established methods $(18,27)$. The histopathologist was blinded to the groups when this analysis was performed.

Immunohistochemistry. Following deparaffinization of prepared skin using xylene, submandibular LN or spleen histological paraffin sections, citrate buffer antigen (epitope) retrieval pretreatment was conducted, as previously described (18). Briefly, a water bath with a staining dish containing $10 \mathrm{mM}$ citrate buffer ( $\mathrm{pH} 6.0$ ) was pre-heated until the temperature reached $95-100^{\circ} \mathrm{C}$. Slides were immersed in the staining dish and the lid was placed loosely on the staining dish. Slides were incubated in the water bath for $20 \mathrm{~min}$ and then the water bath was turned off. Subsequently, the staining dish was placed at room temperature for $20^{\circ} \mathrm{C}$ to allow the slides to cool. Following epitope retrieval, sections were immunostained using avidin-biotin complex (ABC) methods for caspase-3, poly ADP ribose polymerase (PARP), nitrotyrosine (NT), 4-hydroxynonenal (4-HNE), MMP-9, interferon (IFN)- $\gamma$, inducible nitric oxide synthase (iNOS), IL-1 $\beta$, IL-2 and TNF- $\alpha$, following protocols recorded in previous studies $(18,27)$. Briefly, endogenous peroxidase activity was blocked by incubation in methanol and $0.3 \%$ $\mathrm{H}_{2} \mathrm{O}_{2}$ at room temperature for $30 \mathrm{~min}$, and non-specific binding of immunoglobulin was blocked with $1 \%$ normal horse serum blocking solution (1:100; Vector Laboratories, Inc., Burlingame, CA, USA) at room temperature for $1 \mathrm{~h}$ in a humidity chamber. Primary antiserum (listed in Table III) was treated overnight at $4^{\circ} \mathrm{C}$ in a humidity chamber and then incubated with biotinylated universal secondary antibody (Vectastain Elite ABC kit; 1:50; Vector Laboratories, Inc.) and $\mathrm{ABC}$ reagents (Vectastain Elite $\mathrm{ABC}$ kit; 1:50; Vector Laboratories, Inc.) for $1 \mathrm{~h}$ at room temperature in a humidity chamber. Finally, a DAB peroxidase substrate kit (cat. no. SK-4100; Vector Laboratories, Inc.) was applied for $3 \mathrm{~min}$ at room temperature. All sections were rinsed in 0.01 M PBS three times between steps. The cells or fibers occupied by $>30 \%$ of immunoreactivities, the density of each antiserum (for caspase-3, PARP, NT, 4-HNE, MMP-9, IFN- $\gamma$, iNOS, IL-1 $\beta$, IL-2 and TNF- $\alpha$ ) as compared with intact dermal keratinocytes or dermal fibers, were regarded as positive, and the mean numbers of caspase-3, PARP, NT and 4-HNE immunoreactive cells in the epidermis (cells/100 epithelial cells), and mean IFN- $\gamma$, iNOS, IL-1 $\beta$, IL-2 and TNF- $\alpha$ immunolabeled cell numbers in the dermis $\left(\right.$ cells $/ \mathrm{mm}^{2}$ of dermis), spleen (cells $/ \mathrm{mm}^{2}$ of spleen) and submandibular LN (cells $/ \mathrm{mm}^{2}$ of $\mathrm{LN}$ ) were also counted using an automated image analysis process (iSolution FL v. 9.1; IMT i-Solution Inc., Irvine, CA, USA), as previously described $(18,27)$ with some modifications. In addition, the occupied percentages by MMP-9 immunoreactive fibers were also calculated in the dermis $\left(\% / \mathrm{mm}^{2}\right.$ of dermis) as MMP-9 immunoreactivities in the present experiment. The histopathologist was blinded to the group distribution when performing the analysis.

Statistical analyses. All data were expressed as the mean \pm standard deviation of eight hairless mice. Multiple comparison tests for different dose groups were conducted. Variance homogeneity was examined using Levene's tests. If the Levene's test indicated no significant deviations from variance homogeneity, the obtained data were analyzed by one way analysis of variance, followed by least-significant differences multi-comparison test to determine which pairs of group comparison were significantly different. In the case of significant deviations from variance homogeneity being observed in the Levene's test, a non-parametric comparison test, Kruskal-Wallis H test, was conducted. When a significant difference was observed with the Kruskal-Wallis $\mathrm{H}$ test, the Mann-Whitney U test was conducted to determine the specific pairs of group comparisons that were significantly different. Statistical analyses were conducted using SPSS v. 14.0 for Windows (SPSS, Inc., Chicago, IL, USA). In addition, the percentage changes between intact vehicle and DNCB control were calculated to observe the severities of AD-like lesions induced by DNCB in the present study, and the percentage changes as compared with DNCB control and hairless mice bathing in seawaters or receiving 
Table III. Primary antiserum and detection kits used in this study.

\begin{tabular}{|c|c|c|c|}
\hline Product & Catalog number & Supplier & Dilution \\
\hline \multicolumn{4}{|l|}{ Primary antiserums } \\
\hline $\begin{array}{l}\text { Anti-cleaved caspase- } 3 \\
\text { (Asp175) polyclonal antibody }\end{array}$ & 9661 & $\begin{array}{l}\text { Cell Signaling Technology Inc., } \\
\text { Danvers, MA, USA }\end{array}$ & $1: 400$ \\
\hline $\begin{array}{l}\text { Anti-cleaved poly(ADP-ribose) } \\
\text { polymerase (Asp214) specific antibody }\end{array}$ & 9545 & Cell Signaling Technology Inc. & $1: 100$ \\
\hline $\begin{array}{l}\text { Anti-4-Hydroxynonenal polyclonal } \\
\text { antibody }\end{array}$ & $\mathrm{Ab} 46545$ & Abcam, Cambridge, UK & $1: 100$ \\
\hline $\begin{array}{l}\text { Anti-Nitrotyrosine polyclonal } \\
\text { antibody }\end{array}$ & $06-284$ & $\begin{array}{l}\text { EMD Millipore, Billerica, } \\
\text { MA, USA }\end{array}$ & $1: 200$ \\
\hline $\begin{array}{l}\text { Anti- Matrix metalloprotease- } 9 \\
\text { mouse antibody }\end{array}$ & Ab38898 & Abcam & $1: 100$ \\
\hline Anti-interferon $\gamma$ antibody & AF781 & $\begin{array}{l}\text { R\&D Systems, Inc., } \\
\text { Minneapolis, MN, USA }\end{array}$ & $1: 100$ \\
\hline Anti-IL-2 antibody & BAF1815 & R\&D Systems, Inc. & $1: 100$ \\
\hline Anti-tumor necrosis factor- $\alpha$ antibody & sc-52746 & $\begin{array}{l}\text { Santa Cruz Biotechnology, Inc., } \\
\text { Dallas, TX, USA }\end{array}$ & $1: 200$ \\
\hline $\begin{array}{l}\text { Anti-nitric oxide synthase } 2(\mathrm{~N}-20) \\
\text { polyclonal antibody }\end{array}$ & sc-651 & Santa Cruz Biotechnology, Inc. & $1: 100$ \\
\hline $\begin{array}{l}\text { Anti-IL-1 } \beta(\mathrm{H}-153) \text { polyclonal } \\
\text { antibody }\end{array}$ & sc-7884 & Santa Cruz Biotechnology, Inc. & $1: 100$ \\
\hline \multicolumn{4}{|l|}{ Detection kits } \\
\hline Vectastain Elite ABC Kit & PK-6200 & $\begin{array}{l}\text { Vector Laboratories, Inc., } \\
\text { Burlingame, CA, USA }\end{array}$ & $1: 50$ \\
\hline Peroxidase substrate kit & SK-4100 & Vector Laboratories, Inc. & $1: 50$ \\
\hline
\end{tabular}

All antiserums were diluted with $0.01 \mathrm{M}$ phosphate buffered saline. IL, interleukin.

topical application of $1 \%$ DEXA were also calculated to aid the understanding of the efficacy of seawater treatment, as described previously (28).

\section{Results}

Changes in body weight. No significant differences in body weight gains were observed among any of the groups during the total 11-week experimental period. During the 6-week bathing period, DNCB control mice demonstrated similar body weights to the intact vehicle control mice, apart from significant decreases in body weight identified in the DNCB-sensitized (DEXA-treated and ESGWc 100-, 200-, or 400-fold) mice on days 6 and 7 days after initial DNCB sensitization compared with the intact vehicle control mice $(\mathrm{P}<0.05)$. Topical application of $1 \%$ DEXA and bathing with all three concentrations of ESGWc did not significantly alter body weight compared with mice in the DNCB control group throughout the entire experimental period of the present experiment (Fig. 1).

Clinical skin severity score changes. DNCB control mice exhibited significant increases in clinical skin severity scores from $24 \mathrm{~h}$ before initial bathing up until the end of the experimental period compared with intact vehicle control mice $(\mathrm{P}<0.05$; Table IV). However, significant decreases in clinical

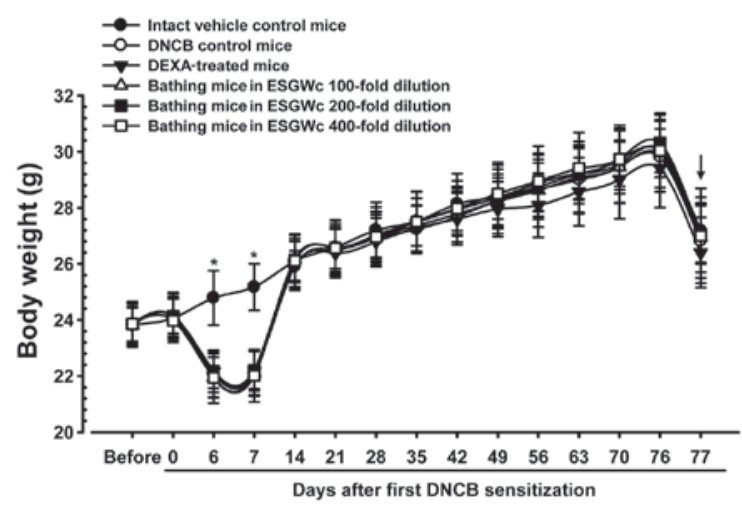

Figure 1. Body weight changes during 6 weeks bathing in ESGWc or topical application of $1 \%$ DEXA in mice with DNCB-induced AD. On day 7, DNCB boosting was initiated and bathing in ESGWc or application of DEXA began on day 35 . The arrow indicated that all animals were fasted overnight on day 77 prior to sacrifice. Values are expressed as the mean \pm standard deviation $(\mathrm{n}=8)$. ${ }^{*} \mathrm{P}<0.05$ vs. all treatment groups. AD, allergic/atopic-like dermatitis; DNCB, 2,4-dinitrochlorobenzene; DEXA, dexamethasone; ESGWc, east saline groundwater concentration solution (50X); Before, 1 day before initial DNCB sensitization.

skin severity scores were observed in mice receiving topical application of $1 \%$ DEXA, from 1 week after initial topical application up until the end of the experiment, as compared with DNCB control mice $(\mathrm{P}<0.05)$. Significant decreases in 
Table IV. Changes to clinical skin severity scores during 6 weeks of bathing in ESGWc or topical application of DEXA in mice with DNCB-induced AD.

\begin{tabular}{|c|c|c|c|c|c|c|}
\hline \multirow{2}{*}{$\begin{array}{l}\text { Days following initial } \\
\text { DNCB sensitization }\end{array}$} & \multicolumn{2}{|c|}{ Controls } & \multirow[b]{2}{*}{ DEXA } & \multicolumn{3}{|c|}{ Bathing in ESGWc dilutions } \\
\hline & Intact & DNCB & & 100-fold & 200 -fold & 400 -fold \\
\hline 35 & $1.00 \pm 0.76$ & $12.38 \pm 1.06^{\mathrm{a}}$ & $12.50 \pm 0.93^{\mathrm{a}}$ & $12.38 \pm 0.92^{\mathrm{a}}$ & $12.50 \pm 1.20^{\mathrm{a}}$ & $12.50 \pm 1.25^{\mathrm{a}}$ \\
\hline 38 & $1.00 \pm 0.76$ & $12.38 \pm 1.06^{\mathrm{a}}$ & $12.13 \pm 0.83^{\mathrm{a}}$ & $12.13 \pm 1.25^{\mathrm{a}}$ & $12.13 \pm 0.83^{\mathrm{a}}$ & $12.13 \pm 1.36^{\mathrm{a}}$ \\
\hline 42 & $1.13 \pm 0.99$ & $11.75 \pm 1.04^{\mathrm{a}}$ & $9.88 \pm 0.99^{a, b}$ & $10.88 \pm 0.99^{\mathrm{a}}$ & $11.00 \pm 1.07^{\mathrm{a}}$ & $11.13 \pm 1.13^{\mathrm{a}}$ \\
\hline 49 & $0.88 \pm 0.64$ & $11.25 \pm 1.28^{\mathrm{a}}$ & $7.38 \pm 1.06^{\mathrm{a}, \mathrm{b}}$ & $8.88 \pm 1.13^{\mathrm{a}, \mathrm{b}}$ & $9.63 \pm 1.19^{\mathrm{a}, \mathrm{b}}$ & $9.88 \pm 0.99^{\mathrm{a}, \mathrm{b}}$ \\
\hline 56 & $0.88 \pm 0.64$ & $10.38 \pm 0.92^{\mathrm{a}}$ & $6.00 \pm 0.76^{\mathrm{a}, \mathrm{b}}$ & $7.00 \pm 1.20^{\mathrm{a}, \mathrm{b}}$ & $8.25 \pm 1.28^{\mathrm{a}, \mathrm{b}}$ & $9.00 \pm 1.07^{\mathrm{a}, \mathrm{b}}$ \\
\hline 63 & $1.25 \pm 0.71$ & $9.75 \pm 1.28^{\mathrm{a}}$ & $4.25 \pm 1.04^{\mathrm{a}, \mathrm{b}}$ & $5.38 \pm 0.92^{\mathrm{a}, \mathrm{b}}$ & $7.13 \pm 1.55^{\mathrm{a}, \mathrm{b}}$ & $8.00 \pm 0.93^{\mathrm{a}, \mathrm{b}}$ \\
\hline 70 & $1.38 \pm 0.74$ & $9.50 \pm 1.31^{\mathrm{a}}$ & $3.38 \pm 1.19^{\mathrm{a}, \mathrm{b}}$ & $4.88 \pm 0.64^{\mathrm{a}, \mathrm{b}}$ & $6.38 \pm 0.92^{\mathrm{a}, \mathrm{b}}$ & $7.25 \pm 0.71^{\mathrm{a}, \mathrm{b}}$ \\
\hline 77 & $1.38 \pm 0.74$ & $8.88 \pm 1.46^{a}$ & $2.88 \pm 1.13^{\mathrm{a}, \mathrm{b}}$ & $3.88 \pm 0.83^{\mathrm{a}, \mathrm{b}}$ & $5.13 \pm 0.99^{\mathrm{a}, \mathrm{b}}$ & $6.63 \pm 0.74^{\mathrm{a}, \mathrm{b}}$ \\
\hline
\end{tabular}

Values are expressed as the mean \pm standard deviation $(n=8)$. Maximum scores were $15 .{ }^{a} \mathrm{P}<0.05$ vs. Intact control; ${ }^{b} \mathrm{P}<0.05$ vs. $\mathrm{DNCB}$ control. $\mathrm{AD}$, allergic/atopic-like dermatitis; DNCB, 2,4-dinitrochlorobenzene; DEXA, dexamethasone; ESGWc, east saline ground water concentration solution $(50 \mathrm{X})$.

Table V. Changes in scratching behaviors during 6 weeks of bathing in ESGWc or topical application of DEXA in mice with DNCB-induced AD.

\begin{tabular}{|c|c|c|c|c|c|c|}
\hline \multirow{2}{*}{$\begin{array}{l}\text { Days after initial } \\
\text { DNCB sensitization }\end{array}$} & \multicolumn{2}{|c|}{ Controls } & \multirow[b]{2}{*}{ DEXA } & \multicolumn{3}{|c|}{ Bathing in ESGWc dilutions } \\
\hline & Intact & DNCB & & 100-fold & 200 -fold & 400-fold \\
\hline 35 & $11.88 \pm 5.46$ & $477.63 \pm 101.18^{\mathrm{a}}$ & $478.88 \pm 77.58^{\mathrm{a}}$ & $478.75 \pm 113.11^{\mathrm{a}}$ & $476.13 \pm 105.78^{a}$ & $483.25 \pm 98.13^{\mathrm{a}}$ \\
\hline 38 & $10.88 \pm 4.05$ & $474.25 \pm 72.20^{\mathrm{a}}$ & $452.63 \pm 68.02^{\mathrm{a}}$ & $459.38 \pm 105.89^{\mathrm{a}}$ & $442.63 \pm 87.99^{\mathrm{a}}$ & $453.63 \pm 79.81^{\mathrm{a}}$ \\
\hline 42 & $12.63 \pm 3.70$ & $467.50 \pm 73.14^{\mathrm{a}}$ & $366.50 \pm 50.54^{\mathrm{a}, \mathrm{b}}$ & $407.25 \pm 88.80^{\mathrm{a}}$ & $419.88 \pm 79.74^{\mathrm{a}}$ & $420.13 \pm 68.88^{\mathrm{a}}$ \\
\hline 49 & $13.38 \pm 4.00$ & $442.38 \pm 73.82^{\mathrm{a}}$ & $281.50 \pm 34.79^{\mathrm{a}, \mathrm{b}}$ & $341.25 \pm 72.07^{\mathrm{a}, \mathrm{b}}$ & $364.50 \pm 54.56^{\mathrm{a}, \mathrm{b}}$ & $373.38 \pm 37.08^{\mathrm{a}, \mathrm{b}}$ \\
\hline 56 & $14.50 \pm 3.70$ & $424.75 \pm 72.51^{\mathrm{a}}$ & $204.50 \pm 20.35^{\mathrm{a}, \mathrm{b}}$ & $255.38 \pm 53.83^{\mathrm{a}, \mathrm{b}}$ & $320.75 \pm 60.23^{\mathrm{a}, \mathrm{b}}$ & $339.38 \pm 33.87^{\mathrm{a}, \mathrm{b}}$ \\
\hline 63 & $14.88 \pm 4.16$ & $405.88 \pm 73.21^{\mathrm{a}}$ & $188.38 \pm 16.65^{\mathrm{a}, \mathrm{b}}$ & $204.13 \pm 29.86^{\mathrm{a}, \mathrm{b}}$ & $241.75 \pm 51.25^{\mathrm{a}, \mathrm{b}}$ & $280.63 \pm 44.71^{\mathrm{a}, \mathrm{b}}$ \\
\hline 70 & $15.63 \pm 3.93$ & $384.38 \pm 54.37^{\mathrm{a}}$ & $146.13 \pm 32.39^{\mathrm{a}, \mathrm{b}}$ & $174.88 \pm 33.47^{\mathrm{a}, \mathrm{b}}$ & $195.13 \pm 20.70^{\mathrm{a}, \mathrm{b}}$ & $252.38 \pm 47.88^{\mathrm{a}, \mathrm{t}}$ \\
\hline 77 & $18.25 \pm 4.77$ & $380.25 \pm 49.69^{a}$ & $76.25 \pm 23.66^{\mathrm{a}, \mathrm{b}}$ & $138.88 \pm 42.58^{\mathrm{a}, \mathrm{b}}$ & $169.88 \pm 23.04^{\mathrm{a}, \mathrm{b}}$ & $218.25 \pm 46.37^{\mathrm{a}, \mathrm{b}}$ \\
\hline
\end{tabular}

Values are expressed as the mean \pm standard deviation scratching behavior frequencies $/ 30 \mathrm{~min}(\mathrm{n}=8) .{ }^{\mathrm{P}} \mathrm{P}<0.05 \mathrm{vs}$. Intact control; ${ }^{\mathrm{b}} \mathrm{P}<0.05$ vs. DNCB control. AD, allergic/atopic-like dermatitis; DNCB, 2,4-dinitrochlorobenzene; DEXA, dexamethasone; ESGWc, east saline ground water concentration solution (50X).

clinical skin severity scores were detected from 2 weeks after initial bathing in ESGWc 100-, 200- and 400-fold dilutions, as compared with DNCB control mice throughout the experimental period $(\mathrm{P}<0.05$; Table IV).

Changes in scratching behavior. DNCB control mice exhibited significant increases in scratching behavior from $24 \mathrm{~h}$ before initial bathing up until the end of the experimental period, as compared with intact vehicle control mice $(\mathrm{P}<0.05$; Table V). However, these increases in scratching behavior were significantly inhibited by topical application of $1 \%$ DEXA from 1 week after initial topical application until the end of the experimental period, compared with DNCB control mice $(\mathrm{P}<0.05)$. In addition, significant decreases in scratching behaviors were detected from 2 weeks after initial bathing in all three concentrations of ESGW in a concentration-dependent manner, compared with DNCB control mice throughout the experimental period $(\mathrm{P}<0.05$; Table $\mathrm{V})$.

Effects on total serum IgE levels. Significant increases in total serum IgE levels were detected in DNCB control mice compared with intact vehicle control mice $(\mathrm{P}<0.05$; Fig. 2$)$. However, significant decreases of total serum IgE levels were detected by topical treatment of $1 \%$ DEXA and also by bathing in ESGWc at 100-, 200- and 400-fold dilutions, in a concentration-dependent manner, compared with DNCB control mice ( $\mathrm{P}<0.05$; Fig. 2$)$.

Changes in submandibular $L N$ and spleen weights. Significant increases of submandibular LN and spleen absolute and relative weights were detected in DNCB control mice compared with intact vehicle control mice $(\mathrm{P}<0.05$; Table VI). However, 
Table VI. Changes in lymphatic organ weights after 6 weeks of bathing in ESGWc or topical application of DEXA in mice with DNCB-induced AD.

\begin{tabular}{|c|c|c|c|c|}
\hline \multirow[b]{2}{*}{ Group } & \multicolumn{2}{|c|}{ Absolute weight, $g$} & \multicolumn{2}{|c|}{ Relative weight, $\%$ of body weight } \\
\hline & Spleen & Submandibular LN & Spleen & Submandibular LN \\
\hline \multicolumn{5}{|l|}{ Controls } \\
\hline Intact & $0.093 \pm 0.012$ & $0.008 \pm 0.002$ & $0.341 \pm 0.051$ & $0.028 \pm 0.009$ \\
\hline DNCB & $0.242 \pm 0.023^{\mathrm{a}}$ & $0.020 \pm 0.002^{\mathrm{a}}$ & $0.905 \pm 0.099^{\mathrm{a}}$ & $0.074 \pm 0.008^{\mathrm{a}}$ \\
\hline \multicolumn{5}{|l|}{ Reference } \\
\hline DEXA & $0.125 \pm 0.017^{\mathrm{a}, \mathrm{b}}$ & $0.011 \pm 0.003^{\mathrm{a}, \mathrm{b}}$ & $0.474 \pm 0.081^{\mathrm{a}, \mathrm{b}}$ & $0.040 \pm 0.013^{\mathrm{a}, \mathrm{b}}$ \\
\hline \multicolumn{5}{|c|}{ ESGWc dilutions } \\
\hline 100-fold & $0.162 \pm 0.013^{\mathrm{a}, \mathrm{b}}$ & $0.013 \pm 0.002^{\mathrm{a}, \mathrm{b}}$ & $0.604 \pm 0.057^{\mathrm{a}, \mathrm{b}}$ & $0.049 \pm 0.009^{\mathrm{a}, \mathrm{b}}$ \\
\hline 200-fold & $0.181 \pm 0.017^{\mathrm{a}, \mathrm{b}}$ & $0.015 \pm 0.002^{\mathrm{a}, \mathrm{b}}$ & $0.668 \pm 0.052^{\mathrm{a}, \mathrm{b}}$ & $0.055 \pm 0.009^{\mathrm{a}, \mathrm{b}}$ \\
\hline 400-fold & $0.198 \pm 0.014^{\mathrm{a}, \mathrm{b}}$ & $0.016 \pm 0.001^{\mathrm{a}, \mathrm{b}}$ & $0.739 \pm 0.090^{\mathrm{a}, \mathrm{b}}$ & $0.060 \pm 0.006^{\mathrm{a}, \mathrm{b}}$ \\
\hline
\end{tabular}

Values are expressed as the mean \pm standard deviation $(\mathrm{n}=8) .{ }^{\mathrm{a}} \mathrm{P}<0.05 \mathrm{vs}$. Intact control; ${ }^{\mathrm{b}} \mathrm{P}<0.05 \mathrm{vs}$. DNCB control. AD, allergic/atopic-like dermatitis; DNCB, 2,4-dinitrochlorobenzene; DEXA, dexamethasone; ESGWc, east saline ground water concentration solution (50X); LN, lymph node.

Table VII. Changes in splenic cytokine contents after 6 weeks of bathing in ESGWc or topical application of DEXA in mice with DNCB-induced AD.

\begin{tabular}{|c|c|c|c|}
\hline \multirow[b]{2}{*}{ Group } & \multicolumn{3}{|c|}{ Splenic cytokine contents, pg/mg protein } \\
\hline & Tumor necrosis factor- $\alpha$ & Interleukin- $1 \beta$ & Interleukin-10 \\
\hline \multicolumn{4}{|l|}{ Controls } \\
\hline Intact & $173.33 \pm 31.33$ & $53.97 \pm 16.10$ & $263.06 \pm 128.36$ \\
\hline DNCB & $548.44 \pm 120.26^{\mathrm{a}}$ & $207.87 \pm 44.12^{\mathrm{a}}$ & $718.54 \pm 141.35^{\mathrm{a}}$ \\
\hline \multicolumn{4}{|l|}{ Reference } \\
\hline DEXA & $202.07 \pm 19.19^{\mathrm{a}, \mathrm{b}}$ & $97.47 \pm 20.38^{\mathrm{a}, \mathrm{b}}$ & $324.84 \pm 83.72^{\mathrm{b}}$ \\
\hline \multicolumn{4}{|c|}{ ESGWc dilutions } \\
\hline 100 -fold & $331.46 \pm 39.19^{\mathrm{a}, \mathrm{b}}$ & $127.57 \pm 16.39^{\mathrm{a}, \mathrm{b}}$ & $435.17 \pm 103.85^{\mathrm{a}, \mathrm{b}}$ \\
\hline 200-fold & $369.29 \pm 51.93^{\mathrm{a}, \mathrm{b}}$ & $136.52 \pm 19.78^{\mathrm{a}, \mathrm{b}}$ & $493.76 \pm 96.21^{\mathrm{a}, \mathrm{b}}$ \\
\hline 400-fold & $416.41 \pm 20.43^{\mathrm{a}, \mathrm{b}}$ & $153.86 \pm 17.10^{\mathrm{a}, \mathrm{b}}$ & $535.12 \pm 101.32^{\mathrm{a}, \mathrm{b}}$ \\
\hline
\end{tabular}

Values are expressed as the mean \pm standard deviation $(\mathrm{n}=8)$. ${ }^{\mathrm{P}}<0.05 \mathrm{vs}$. Intact control; ${ }^{\mathrm{b}} \mathrm{P}<0.05 \mathrm{vs}$. DNCB control. AD, allergic/atopic-like dermatitis; DNCB, 2,4-dinitrochlorobenzene; DEXA, dexamethasone; ESGWc, east saline ground water concentration solution (50X).

significant decreases in both absolute and relative submandibular LN and spleen weights were detected following topical application of $1 \%$ DEXA, and also following bathing in all three ESGWc dilutions, concentration-dependently, compared with DNCB control mice $(\mathrm{P}<0.05$; Table VI).

Effects on splenic cytokine contents. Significant increases in splenic tissue TNF- $\alpha$, IL- $1 \beta$ and IL-10 contents were detected in DNCB control mice compared with intact control vehicle mice $(\mathrm{P}<0.05)$. However, significant decreases in splenic tissue TNF- $\alpha$, IL-1 $\beta$ and IL-10 contents were detected following topical treatment of 1\% DEXA and also concentration-dependent decreases were observed following bathing in ESGWc 100-, 200- and 400-fold dilutions, compared with DNCB control mice $(\mathrm{P}<0.05$; Table VII).
Changes to skin tissue cytokine mRNA expression levels (RT-qPCR analysis). Significant increases in the expression of TNF- $\alpha$, IL-4, IL-5 and IL-13 mRNA in the dorsal back skin tissue were detected in DNCB control mice compared with intact vehicle control mice according to RT-qPCR analysis $(\mathrm{P}<0.05$; Table VIII). However, significant decreases in expression of TNF- $\alpha$, IL-4, IL-5 and IL-13 mRNA were observed in skin tissues following topical treatment with $1 \%$ DEXA. Concentration-dependent decreases were also observed following bathing in the three dilutions of ESGWc, compared with DNCB control mice $(\mathrm{P}<0.05$; Table VIII).

Effects on the skin tissue antioxidant defense systems. Significant decreases in dorsal back skin tissue GSH content and significant increases in skin lipid peroxidation and 
Table VIII. Changes in skin mRNA expressions after 6 weeks of bathing in ESGWc or topical application of DEXA in mice with DNCB-induced AD.

Skin mRNA expressions (relative expressions/GAPDH mRNA)

\begin{tabular}{|c|c|c|c|c|}
\hline \multirow[b]{2}{*}{ Groups } & \\
\hline & TNF- $\alpha$ & IL-4 & IL-5 & IL-13 \\
\hline \multicolumn{5}{|l|}{ Controls } \\
\hline Intact & $0.98 \pm 0.08$ & $1.03 \pm 0.13$ & $1.01 \pm 0.09$ & $0.99 \pm 0.07$ \\
\hline DNCB & $6.47 \pm 0.97^{\mathrm{a}}$ & $5.27 \pm 1.08^{\mathrm{a}}$ & $5.92 \pm 1.19^{\mathrm{a}}$ & $3.30 \pm 0.64^{\mathrm{a}}$ \\
\hline \multicolumn{5}{|l|}{ Reference } \\
\hline DEXA & $2.97 \pm 0.71^{\mathrm{a}, \mathrm{b}}$ & $2.03 \pm 0.33^{\mathrm{a}, \mathrm{b}}$ & $2.45 \pm 0.72^{\mathrm{a}, \mathrm{b}}$ & $1.56 \pm 0.32^{\mathrm{a}, \mathrm{b}}$ \\
\hline \multicolumn{5}{|c|}{ ESGWc dilutions } \\
\hline 100 -fold & $3.15 \pm 0.81^{\mathrm{a}, \mathrm{b}}$ & $2.66 \pm 0.36^{\mathrm{a}, \mathrm{b}}$ & $3.31 \pm 0.52^{\mathrm{a}, \mathrm{b}}$ & $1.80 \pm 0.14^{\mathrm{a}, \mathrm{b}}$ \\
\hline 200 -fold & $3.93 \pm 0.80^{\mathrm{a}, \mathrm{b}}$ & $3.30 \pm 0.56^{\mathrm{a}, \mathrm{b}}$ & $3.79 \pm 0.62^{\mathrm{a}, \mathrm{b}}$ & $1.95 \pm 0.13^{\mathrm{a}, \mathrm{b}}$ \\
\hline 400 -fold & $4.71 \pm 1.16^{\mathrm{a}, \mathrm{b}}$ & $3.70 \pm 0.83^{\mathrm{a}, \mathrm{b}}$ & $4.17 \pm 0.51^{\mathrm{a}, \mathrm{b}}$ & $2.36 \pm 0.46^{\mathrm{a}, \mathrm{b}}$ \\
\hline
\end{tabular}

Values are expressed as the mean \pm standard deviation. $(\mathrm{n}=8)$. ${ }^{\mathrm{a}} \mathrm{P}<0.05$ vs. Intact control; ${ }^{\mathrm{b}} \mathrm{P}<0.05 \mathrm{vs}$. DNCB control. AD, allergic/atopic-like dermatitis; DNCB, 2,4-dinitrochlorobenzene; DEXA, dexamethasone; ESGWc, east saline ground water concentration solution (50X); TNF, tumor necrosis factor; IL, interleukin.

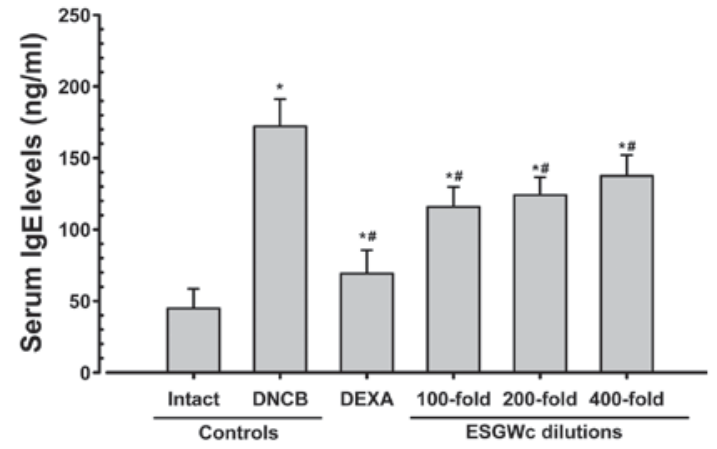

Figure 2. Changes in serum IgE levels following 6 weeks bathing in ESGWc or topical application of DEXA in mice with DNCB-induced AD. Values are expressed as the mean \pm standard deviation $(\mathrm{n}=8)$. ${ }^{*} \mathrm{P}<0.05$ vs. Intact control; ${ }^{\#} \mathrm{P}<0.05$ vs. DNCB control. AD, allergic/atopic-like dermatitis; DNCB, 2,4-dinitrochlorobenzene; DEXA, dexamethasone; ESGWc, east saline groundwater concentration solution (50X); $\operatorname{IgE}$, immunoglobulin E.

superoxide anion production were observed in DNCB control mice compared with intact vehicle control mice $(\mathrm{P}<0.05$; Table IX). However, compared with DNCB control mice, there were significant increases in GSH content and significant decreases in lipid peroxidation and superoxide anion production in the skin tissues of mice bathing in ESGWc 100-, 200- and 400-fold dilutions, in a concentration-dependent manner $(\mathrm{P}<0.05)$. Topical application of $1 \%$ DEXA did not significantly influence skin tissue antioxidant defense systems compared with DNCB control mice (Table IX).

Histopathological changes on the dorsal back skin tissues. A significant increase in mean epithelial thickness due to hyperplasia/hypertrophy of epidermal keratinocytes was detected in the dorsal back skin tissues of DNCB control mice, with significant increases in the numbers of mast and inflammatory cells infiltrating into dermis, compared with mice in the intact vehicle control group $(\mathrm{P}<0.05$; Table $\mathrm{X}$; Fig. 3$)$.
Abnormal collagen depositions, elevations of caspase-3, PARP, NT and 4-HNE immunoreactive epidermal cells, dermal MMP-9 immunoreactivities, infiltrations of dermal IFN- $\gamma$, iNOS, IL-1 $\beta$, IL- 2 and TNF- $\alpha$ immunolabeled cells were also observed in the DNCB control group compared with the intact vehicle control group (Figs. 3-5). These results were confirmed by histomorphometrical analysis, which demonstrated significant increases in mean epithelial thickness, numbers of dermal infiltrated mast and inflammatory cells, percentages of collagen fiber-occupied dermal regions, caspase-3, PARP, NT and 4-HNE immunoreactive epidermal cells, dermal IFN- $\gamma$, iNOS, IL- $1 \beta$, IL- 2 and TNF- $\alpha$ immunolabeled cells in DNCB control mice compared with intact vehicle control mice (all $\mathrm{P}<0.05$; Table $\mathrm{XI}$ ). However, these histopathological hypersensitivity-related AD signs were significantly inhibited by bathing in the ESGWc 100-, 200- and 400-fold dilutions, in a concentration-dependent manner, compared with DNCB control mice $(\mathrm{P}<0.05$; Tables X and XI). Topical application of $1 \%$ DEXA also significantly reduced the increases of mean epithelial thicknes, numbers of dermal infiltrated mast and inflammatory cells, caspase-3, PARP, NT and 4-HNE immunoreactive epidermal cells, dermal MMP-9 immunoreactivities, dermal IFN- $\gamma$, iNOS, IL-1 $\beta$, IL-2 and TNF- $\alpha$ immunolabeled cells induced by NDCB treatment $(\mathrm{P}<0.05$; Tables $\mathrm{X}$ and $\mathrm{XI})$; however, 1\% DEXA did not signifcantly influence the percentage of collagen fiber-occupied dermal regions, as compared with DNCB control mice (Table X).

Histopathological changes in splenic tissues. Marked hypertrophic changes due to hyperplasia of red pulp lymphoid cells were detected in the splenic tissues of DNCB control mice, with marked increases of the numbers of IFN- $\gamma$, iNOS, IL-1 $\beta$, IL-2 and TNF- $\alpha$ immunolabeled cells (Figs. 6 and 7). These results were confirmed by histomorphometrical analysis, which demonstrated significant increases in total splenic thicknesses, numbers of red pulp lymphoid cells, 
Table IX. Changes in skin antioxidant defense systems after 6 weeks of continuous bathing in ESGWc or topical application of DEXA in mice with DNCB-induced AD.

\begin{tabular}{|c|c|c|c|}
\hline \multirow[b]{2}{*}{ Groups } & \multicolumn{3}{|c|}{ Skin antioxidant defense systems } \\
\hline & Glutathione, $\mu \mathrm{M} / \mathrm{mg}$ of protein & $\begin{array}{l}\text { Lipid peroxidation- } \\
\text { Malondialdehyde, } \mathrm{nM} / \mathrm{mg} \\
\text { of protein }\end{array}$ & $\begin{array}{c}\text { Superoxide anion } \\
\text { production, NBT reduction/ } \\
\text { OD at } 600 \mathrm{~nm}\end{array}$ \\
\hline \multicolumn{4}{|l|}{ Controls } \\
\hline Intact & $1.56 \pm 0.32$ & $0.44 \pm 0.16$ & $0.42 \pm 0.19$ \\
\hline DNCB & $0.37 \pm 0.15^{\mathrm{a}}$ & $2.87 \pm 0.69^{\mathrm{a}}$ & $1.80 \pm 0.19^{\mathrm{a}}$ \\
\hline \multicolumn{4}{|l|}{ Reference } \\
\hline DEXA & $0.34 \pm 0.07^{\mathrm{a}}$ & $3.00 \pm 0.95^{\mathrm{a}}$ & $1.85 \pm 0.18^{\mathrm{a}}$ \\
\hline \multicolumn{4}{|c|}{ Bathing in ESGWc dilutions } \\
\hline 100-fold & $0.97 \pm 0.17^{\mathrm{a}, \mathrm{b}}$ & $1.26 \pm 0.27^{\mathrm{a}, \mathrm{b}}$ & $0.91 \pm 0.14^{\mathrm{a}, \mathrm{b}}$ \\
\hline 200-fold & $0.82 \pm 0.11^{\mathrm{a}, \mathrm{b}}$ & $1.49 \pm 0.26^{\mathrm{a}, \mathrm{b}}$ & $1.12 \pm 0.22^{\mathrm{a}, \mathrm{b}}$ \\
\hline 400-fold & $0.68 \pm 0.11^{\mathrm{a}, \mathrm{b}}$ & $1.83 \pm 0.20^{\mathrm{a}, \mathrm{b}}$ & $1.26 \pm 0.20^{\mathrm{a}, \mathrm{b}}$ \\
\hline
\end{tabular}

Values are expressed as the mean \pm standard deviation $(\mathrm{n}=8) .{ }^{\mathrm{a}} \mathrm{P}<0.05 \mathrm{vs}$. Intact control; ${ }^{\mathrm{b}} \mathrm{P}<0.05 \mathrm{vs}$. DNCB control. AD, allergic/atopic-like dermatitis; DNCB, 2,4-dinitrochlorobenzene; DEXA, dexamethasone; ESGWc, east saline ground water concentration solution (50X); TNF, tumor necrosis factor; OD, optical density; NBT, nitroblue tetrazolium.

Table X. General skin tissue histomorphometry after 6 weeks of bathing in ESGWc or topical application of DEXA in mice with DNCB-induced AD.

\begin{tabular}{|c|c|c|c|c|c|c|}
\hline \multirow[b]{2}{*}{ Index } & \multicolumn{2}{|c|}{ Controls } & \multirow[b]{2}{*}{ DEXA } & \multicolumn{3}{|c|}{ Bathing in ESGWc dilutions } \\
\hline & Intact & DNCB & & 100-fold & 200-fold & 400-fold \\
\hline Epithelial Th, $\mu \mathrm{m}$ & $34.69 \pm 8.73$ & $117.28 \pm 19.66^{\mathrm{a}}$ & $37.07 \pm 7.07^{\mathrm{a}, \mathrm{b}}$ & $48.49 \pm 11.00^{\mathrm{a}, \mathrm{b}}$ & $54.71 \pm 12.06^{\mathrm{a}, \mathrm{b}}$ & $70.53 \pm 12.16^{\mathrm{a}, \mathrm{b}}$ \\
\hline $\begin{array}{l}\text { Collagen fOP, } \\
\% / \mathrm{mm}^{2} \text { of dermis }\end{array}$ & $41.48 \pm 3.36$ & $77.28 \pm 10.51^{\mathrm{a}}$ & $77.58 \pm 10.65^{\mathrm{a}}$ & $50.24 \pm 10.01^{b}$ & $55.78 \pm 11.16^{\mathrm{a}, \mathrm{b}}$ & $61.86 \pm 10.16^{\mathrm{a}, \mathrm{b}}$ \\
\hline \multicolumn{7}{|l|}{$\begin{array}{l}\text { Infiltrated cells, } \\
\text { cells } / \mathrm{mm}^{2} \text { of dermis }\end{array}$} \\
\hline IF & $27.13 \pm 14.81$ & $409.00 \pm 76.80^{\mathrm{a}}$ & $74.75 \pm 27.06^{\mathrm{a}, \mathrm{b}}$ & $132.75 \pm 33.48^{\mathrm{a}, \mathrm{b}}$ & $211.50 \pm 44.26^{\mathrm{a}, \mathrm{b}}$ & $283.25 \pm 34.05^{\mathrm{a}, \mathrm{b}}$ \\
\hline Mast & $134.34 \pm 40.05$ & $842.75 \pm 109.18^{a}$ & $216.75 \pm 44.52^{b}$ & $381.88 \pm 136.05^{\mathrm{a}, \mathrm{b}}$ & $483.75 \pm 77.75^{\mathrm{a}, \mathrm{b}}$ & $570.25 \pm 111.70^{\mathrm{a}, \mathrm{b}}$ \\
\hline
\end{tabular}

Values are expressed as the mean \pm standard deviation $(\mathrm{n}=8) .{ }^{\mathrm{a}} \mathrm{P}<0.05$ vs. Intact control; ${ }^{\mathrm{b}} \mathrm{P}<0.05 \mathrm{vs}$. DNCB control. AD, allergic/atopic-like dermatitis; DNCB, 2,4-dinitrochlorobenzene; DEXA, dexamethasone; ESGWc, east saline ground water concentration solution (50X); Th, thickness; fOP, fiber occupied region percentages; IF, inflammatory.

numbers of IFN- $\gamma$, iNOS, IL-1 $\beta$, IL-2 and TNF- $\alpha$ immunolabeled cells in DNCB control mice compared with intact vehicle control mice $(\mathrm{P}<0.05$; Table $\mathrm{XII})$. However, these hypersensitivity-related splenic hypertrophic signs were significantly inhibited following topical treatment with $1 \%$ DEXA, and also by bathing in the three dilutions of ESGWc, concentration-dependently, as compared with DNCB control mice $(\mathrm{P}<0.05)$. No significant changes in the number of white pulp cells were demonstrated following treatment with DNCB compared with the intact vehicle control mice, nor by topical application of $1 \%$ DEXA or bathing in ESGWc 100-, 200- and 400-fold dilutions, as compared with DNCB control mice (Table XII).
Histopathological changes in submandibular LN tissues. Marked hypertrophic changes due to hyperplasia of cortex lymphoid cells were detected in submandibular LN tissues in DNCB control mice, with marked increases of the numbers of IFN- $\gamma$, iNOS, IL- $1 \beta$, IL- 2 and TNF- $\alpha$ immunolabeled cells (Figs. 8 and 9). These observations were confirmed by histomorphometrical analysis, which demonstrated significant increases in total submandibular LN thicknesses, numbers of cortex lymphoid follicles, cortex thicknesses, numbers of IFN- $\gamma$, iNOS, IL-1 $\beta$, IL- 2 and TNF- $\alpha$ immunolabeled cells in submandibular LN tissues of DNCB control mice compared with intact vehicle control mice $(\mathrm{P}<0.05$; Table XIII). However, these submandibular LN hypersensitivity-related hypertrophic signs were significantly inhibited by topical treatment of 


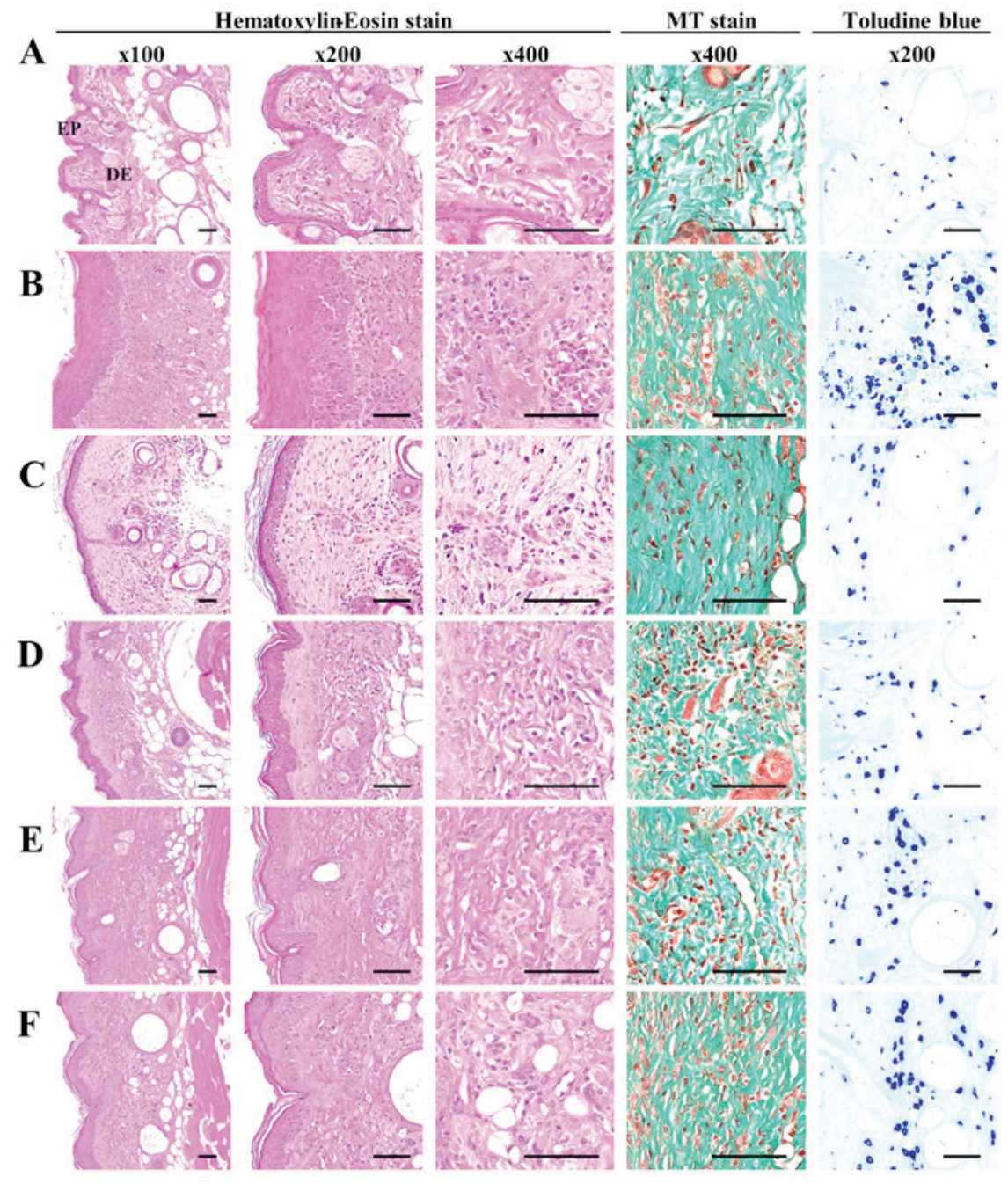

Figure 3. Representative histological images of dorsal back skin tissues taken from unexposed intact mice or mice with DNCB-induced AD following bathing in distilled water or ESGWc, or topical application of DEXA. Histological images from (A) intact vehicle control mice bathing in distilled water, (B) DNCB control mice bathing in distilled water, (C) mice with DNCB-induced AD treated with topical application of $1 \%$ DEXA and mice with DNCB-induced AD following bathing in ESGWc at (D) 100-, (E) 200- and (F) 400-fold dilution. Scale bar, $40 \mu \mathrm{m}$. AD, allergic/atopic-like dermatitis; DNCB, 2,4-dinitrochlorobenzene; DEXA, dexamethasone; ESGWc, east saline groundwater concentration solution (50X); EP, epidermis; DE, dermis; MT, Masson's trichrome.

$1 \%$ DEXA, and also concentration-dependently by bathing in all three dilutions of ESGWc, compared with DNCB control mice $(\mathrm{P}<0.05$; Table XIII).

\section{Discussion}

In the present study, clinical skin severity and scratching behaviors were significantly reduced, and serum total $\operatorname{IgE}$ levels were decreased in mice with DNCB-induced AD following bathing in all ESGWc dilutions, suggesting that bathing in ESGWc inhibited DNCB-induced dermatitis symptoms. Clinical skin severity scores and scratching behaviors were used as an index to select the mice that had developed AD at the end of DNCB sensitization and boosting. Major characteristics of skin lesions of $\mathrm{AD}$ are considered to be infiltration with various inflammatory cells, including mast cells, basophils, eosinophils and $\mathrm{T}$ cells (29), and symptoms, including itching, erythema, eczema skin lesions, chronic relapse and pruritus (1). DNCB-treated skin exhibits inflammation and dermis sclerosis with these common symptoms (30). Thus, clinical skin severity has been used as a meaningful indicator for predicting the progression of AD with scratching behaviors $(3,18)$. In the current study, clinical skin severity was graded based on five signs, which were pruritus/itching, erythema/hemorrhage, edema, excoriation/erosion and scaling/dryness. Mast cell-mediated inflammatory responses cause hypersensitivity and allergic reactions. Upon the cross-linking of their surface $\operatorname{IgE}$ by antigens, IgE-dependent mast cells may be stimulated to degranulate and release histamine, leukotrienes, proteases, prostaglandins and cytokines $(6,18)$. Mast cell activation results in the release of numerous inflammatory mediators through the cross-linking of IgE receptor complexes at the high-affinity IgE receptor I. Of these mediators, histamine is considered as a marker of mast cell degranulation in immediate allergic reactions and is a violent inducer of itching $(6,18)$. Histamine is a characteristic major mediator in mast cell storage granules and directly triggers type I allergic responses $(6,18)$. Marked increases of infiltrated mast cells have been observed in various types of atopic dermatitis $(6,18)$.

Furthermore, the present study demonstrated that bathing in ESGWc dilutions significantly suppressed DNCB-induced systemic and local hypersensitivities in 


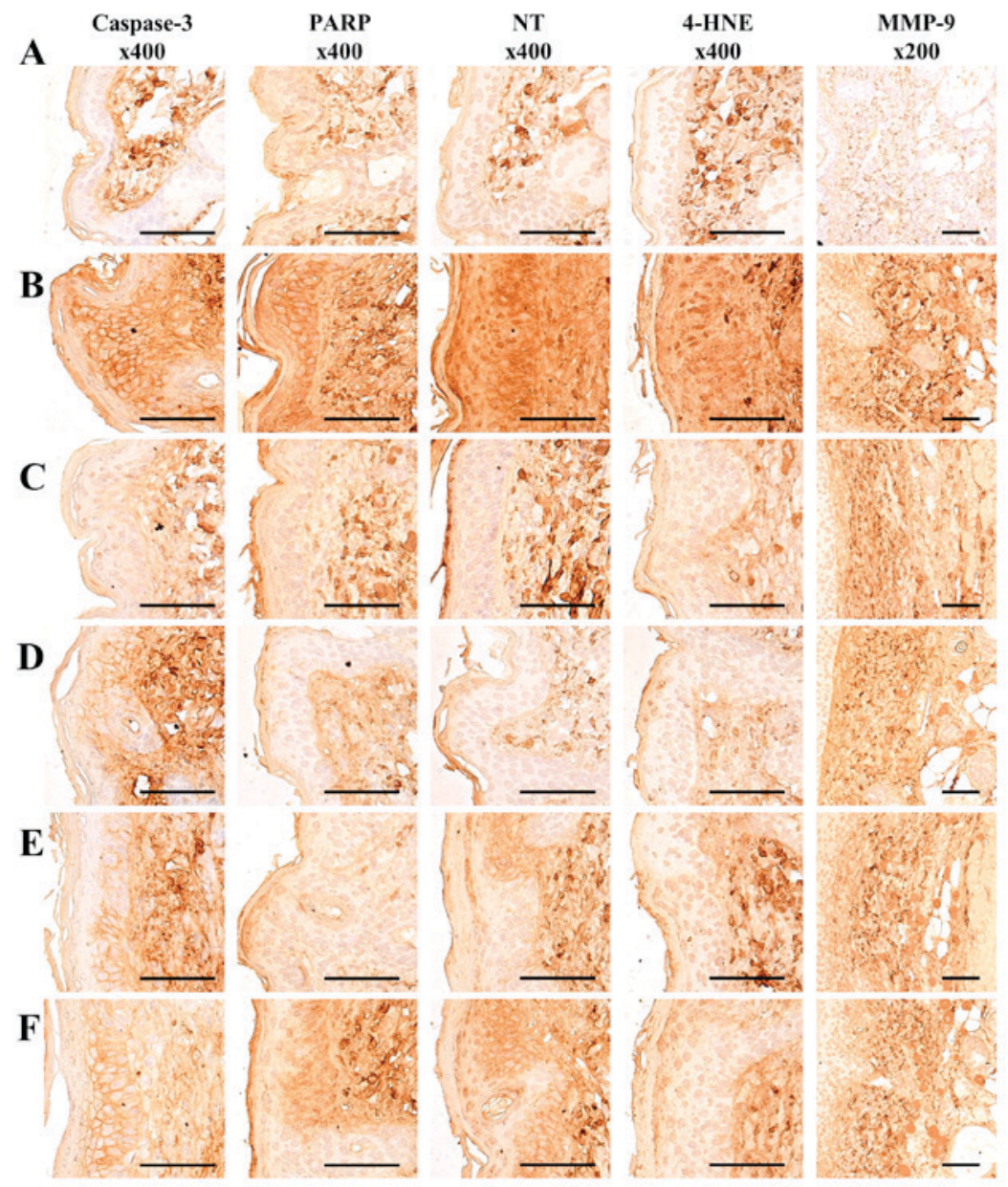

Figure 4. Representative immunohistochemical images of caspase-3, PARP, NT, 4-HNE and MMP-9 in the dorsal back skin tissues taken from unexposed intact mice or mice with DNCB-induced AD following bathing in distilled water or ESGWc, or topical application of DEXA. Immunohistochemical images from (A) intact vehicle control mice bathing in distilled water, (B) DNCB control mice bathing in distilled water, (C) mice with DNCB-induced AD treated with topical application of 1\% DEXA and mice with DNCB-induced AD following bathing in ESGWc at (D) 100-, (E) 200- and (F) 400-fold dilution. Scale bar, $40 \mu \mathrm{m}$. Stain, avidin-biotin complex immunostain. AD, allergic/atopic-like dermatitis; DNCB, 2,4-dinitrochlorobenzene; DEXA, dexamethasone; ESGWc, east saline groundwater concentration solution (50X); PARP, cleaved poly(ADP-ribose) polymerase; NT, nitrotyrosine; 4-HNE, 4-Hydroxynonenal; MMP-9, matrix metalloprotease-9.

concentration-dependent patterns. TNF- $\alpha$, IL-1 $\beta$ and IL-10 levels in spleen tissue were markedly reduced, concomitantly TNF- $\alpha$, IL-4, IL-5 and IL-13 mRNA expression in skin tissue were decreased following bathing in ESGWc dilutions. In addition, bathing in ESGWc dilutions inhibited the IFN- $\gamma$, iNOS, IL-1 $\beta$, IL-2 and TNF- $\alpha$ immunoreactive cells in the local skin, submandibular $\mathrm{LN}$ and spleen tissues. It has previously been reported that hydrotherapy, including with ESGW, was able to modulate lymphocyte proliferation and cytokine production $(13,18)$. AD is a form of delayed-type hypersensitivity reaction induced in susceptible individuals by a variety of low molecular weight chemicals (31). The pathogenesis of $\mathrm{AD}$ is recognized as a complex process mediated by genetic, environmental and immunological factors (32). IL-4, IL-5 and IL-13 produced by Th2 cells may be responsible for the onset and development of AD (32). Although the etiology and pathology of $\mathrm{AD}$ remain unclear, research suggests that typical symptoms of AD include increased levels of Th2-mediated cytokines and a deficiency in Th1-mediated cytokines (33). Th2 cells are primarily involved in the acute phase of $\mathrm{AD}$, while Th1 cells are activated and attribute to pathogenesis in the chronic phase (34). Increased IgE levels are an important indicator of AD and the activation of IL-4 contributes to this elevation. IL-4 triggers IgE production in $\mathrm{B}$ cells and IgE released from B cells binds to mast cells. When sufficient antigen has bound to the $\operatorname{IgE}$, the mast cells degranulate and release various biological mediators, including histamine and heparin, which is mediated by $\operatorname{IgE}$ in $\mathrm{AD}$ (35). $\mathrm{AD}$ is dependent on the release of the cytokines IL-4, IL-5, and IL-13 by Th2 cells that are produced from precursors (36). Many patients with AD have experienced an increase in eosinophils and IgE due to elevated IL-4, IL-5 and IL-13 levels (36). TNF- $\alpha$, a 17-kDa protein that is classified as one of the major products of activated macrophages (37), is a presentative pro-inflammatory cytokine (38). Previous research has demonstrated that TNF- $\alpha$ is markedly increased in DNCB-induced dermatitis (39).

TNF- $\alpha$-mediated inflammation is stimulated by the release of eicosanoids and cytokines, including IL-1 and TNF- $\alpha$ (38). IL-1 may stimulate neutrophils and macrophages by increasing the production and release of reactive oxygen species (ROS) and nitric oxide, which has been implicated in local tissue damage (40). IL-2 is generally produced by T cells during an immune response and is involved in the growth, proliferation 
Table XI. Immunohistochemical skin tissue histomorphometry after 6 weeks of bathing in ESGWc or topical application of DEXA in mice with DNCB-induced AD.

\begin{tabular}{|c|c|c|c|c|c|c|}
\hline \multirow[b]{2}{*}{ Antiserum } & \multicolumn{2}{|c|}{ Controls } & \multirow[b]{2}{*}{ DEXA } & \multicolumn{3}{|c|}{ Bathing in ESGWc dilutions } \\
\hline & Intact & DNCB & & 100-fold & 200-fold & 400-fold \\
\hline Caspase $-3^{\text {a }}$ & $4.75 \pm 3.20$ & $83.50 \pm 11.35^{\mathrm{d}}$ & $35.38 \pm 13.36^{\mathrm{d}, \mathrm{e}}$ & $44.25 \pm 10.01^{\mathrm{d}, \mathrm{e}}$ & $55.13 \pm 12.89^{\mathrm{d}, \mathrm{e}}$ & $65.13 \pm 10.27^{\mathrm{d}}$ \\
\hline PARPa & $6.00 \pm 2.27$ & $84.63 \pm 10.10^{\mathrm{d}}$ & $23.00 \pm 4.72^{\mathrm{d}, \mathrm{e}}$ & $35.63 \pm 10.95^{\mathrm{d}, \mathrm{e}}$ & $42.25 \pm 12.89^{\mathrm{d}, \mathrm{e}}$ & $59.38 \pm 13.75^{\mathrm{d}}$ \\
\hline $\mathrm{NT}^{\mathrm{a}}$ & $17.13 \pm 3.52$ & $85.00 \pm 10.98^{\mathrm{d}}$ & $18.00 \pm 5.07^{\mathrm{e}}$ & $25.13 \pm 10.92^{\mathrm{e}}$ & $51.63 \pm 11.98^{\mathrm{d}, \mathrm{e}}$ & $61.88 \pm 18.65^{\mathrm{d}}$ \\
\hline 4-HNE ${ }^{\mathrm{a}}$ & $5.75 \pm 2.49$ & $81.83 \pm 11.10^{\mathrm{d}}$ & $24.63 \pm 4.75^{\mathrm{d}, \mathrm{e}}$ & $31.00 \pm 12.49^{\mathrm{d}, \mathrm{e}}$ & $40.75 \pm 15.57^{\mathrm{d}, \mathrm{e}}$ & $54.63 \pm 10.46^{\mathrm{d}}$ \\
\hline MMP-9 & $9.24 \pm 3.15$ & $59.49 \pm 11.07^{\mathrm{d}}$ & $42.12 \pm 5.25^{\mathrm{d}, \mathrm{e}}$ & $27.15 \pm 6.50^{\mathrm{d}, \mathrm{e}}$ & $38.79 \pm 5.56^{\mathrm{a}, \mathrm{e}}$ & $45.97 \pm 5.54^{\mathrm{d}, \mathrm{e}}$ \\
\hline IFN- $\gamma^{\mathrm{c}}$ & $8.15 \pm 2.14$ & $153.93 \pm 12.21^{\mathrm{d}}$ & $41.29 \pm 11.76^{\mathrm{d}, \mathrm{e}}$ & $66.54 \pm 16.83^{\mathrm{d}, \mathrm{e}}$ & $84.70 \pm 21.85^{\mathrm{d}, \mathrm{e}}$ & $120.74 \pm 16.68^{\mathrm{d}}$ \\
\hline iNOS $^{c}$ & $7.15 \pm 1.47$ & $240.40 \pm 34.21^{\mathrm{d}}$ & $78.05 \pm 20.34^{\mathrm{d}, \mathrm{e}}$ & $93.23 \pm 15.87^{\mathrm{d}, \mathrm{e}}$ & $165.69 \pm 23.82^{\mathrm{d}, \mathrm{e}}$ & $189.61 \pm 22.66^{\mathrm{d}}$ \\
\hline IL-1 $1 \beta^{\mathrm{c}}$ & $5.41 \pm 1.54$ & $199.48 \pm 17.25^{\mathrm{d}}$ & $49.44 \pm 12.07^{\mathrm{d}, \mathrm{e}}$ & $85.69 \pm 16.49^{\mathrm{d}, \mathrm{e}}$ & $126.81 \pm 25.93^{\mathrm{d}, \mathrm{e}}$ & $160.10 \pm 20.52^{\mathrm{d}}$ \\
\hline IL-2 ${ }^{\mathrm{c}}$ & $4.13 \pm 1.15$ & $87.08 \pm 21.38^{\mathrm{d}}$ & $19.71 \pm 5.55^{\mathrm{d}, \mathrm{e}}$ & $37.24 \pm 9.30^{\mathrm{d}, \mathrm{e}}$ & $51.58 \pm 11.99^{\mathrm{d}, \mathrm{e}}$ & $60.74 \pm 11.01^{\mathrm{d},}$ \\
\hline TNF- $\alpha^{c}$ & $5.64 \pm 1.50$ & $68.81 \pm 14.21^{\mathrm{d}}$ & $18.21 \pm 3.25^{\mathrm{d}, \mathrm{e}}$ & $23.74 \pm 5.63^{\mathrm{d}, \mathrm{e}}$ & $35.66 \pm 10.87^{\mathrm{d}, \mathrm{e}}$ & $42.26 \pm 10.10^{\mathrm{d},}$ \\
\hline
\end{tabular}

${ }^{\mathrm{a} N u m b e r}$ of immunoreactive cells $/ 100$ epithelial cells; ${ }^{\mathrm{b}} \%$ immunoreactivity $/ \mathrm{mm}^{2}$ of dermis; ${ }^{\mathrm{c}} \mathrm{x} 10$ immunoreactive cells $/ \mathrm{mm}^{2}$ of dermis; ${ }^{\mathrm{d}} \mathrm{P}<0.05$ vs. Intact control; ${ }^{\mathrm{e}} \mathrm{P}<0.05$ vs. DNCB control. Values are expressed as the mean \pm standard deviation $(\mathrm{n}=8)$. AD, allergic/atopic-like dermatitis; DNCB, 2,4-dinitrochlorobenzene; DEXA, dexamethasone; ESGWc, east saline ground water concentration solution (50X); PARP, cleaved poly(ADP-ribose) polymerase; NT, nitrotyrosine; 4-HNE, 4-hydroxynonenal; MMP, matrix metalloprotease; IFN, interferon; IL, interleukin; iNOS, inducible nitric oxide synthase; TNF, tumor necrosis factor.

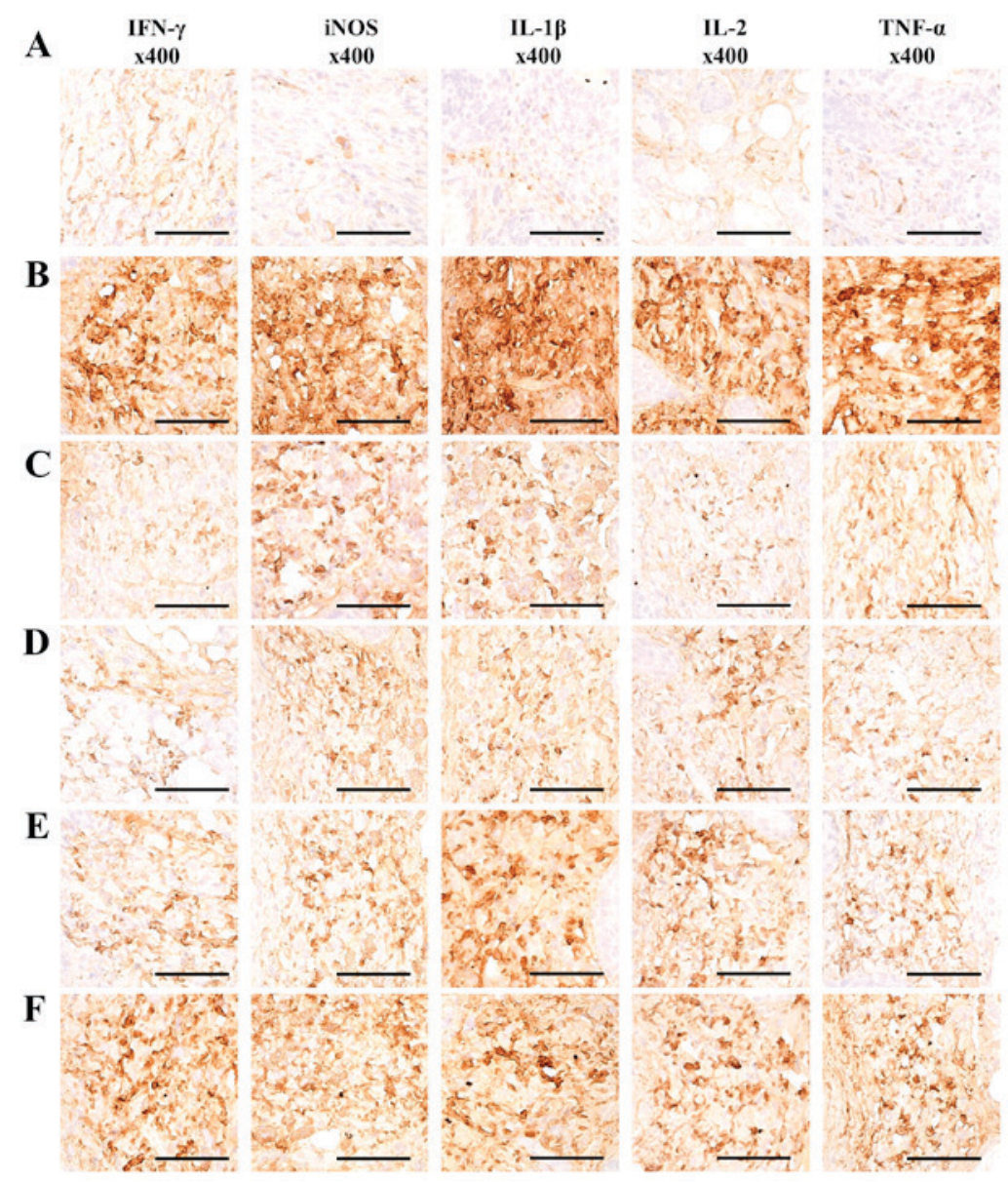

Figure 5. Representative immunohistochemical images of dermal IFN- $\gamma$, iNOS, IL-1 $\beta$, IL-2 and TNF- $\alpha$ in the dorsal back skin tissues taken from unexposed intact mice or mice with DNCB-induced AD following bathing in distilled water or ESGWc, or receiving topical application of DEXA. Immunohistochemical images from (A) intact vehicle control mice bathing in distilled water, (B) DNCB control mice bathing in distilled water, (C) mice with DNCB-induced AD treated with topical application of 1\% DEXA and mice with DNCB-induced AD following bathing in ESGWc at (D) 100-, (E) 200- and (F) 400 -fold dilution. Scale bar, 40 $\mu$ m. Stain, avidin-biotin complex immunostain. AD, allergic/atopic-like dermatitis; DNCB, 2,4-dinitrochlorobenzene; DEXA, dexamethasone; ESGWc, east saline groundwater concentration solution (50X); IFN, interferon; IL, interleukin; iNOS, inducible nitric oxide synthase; TNF, tumor necrosis factor. 


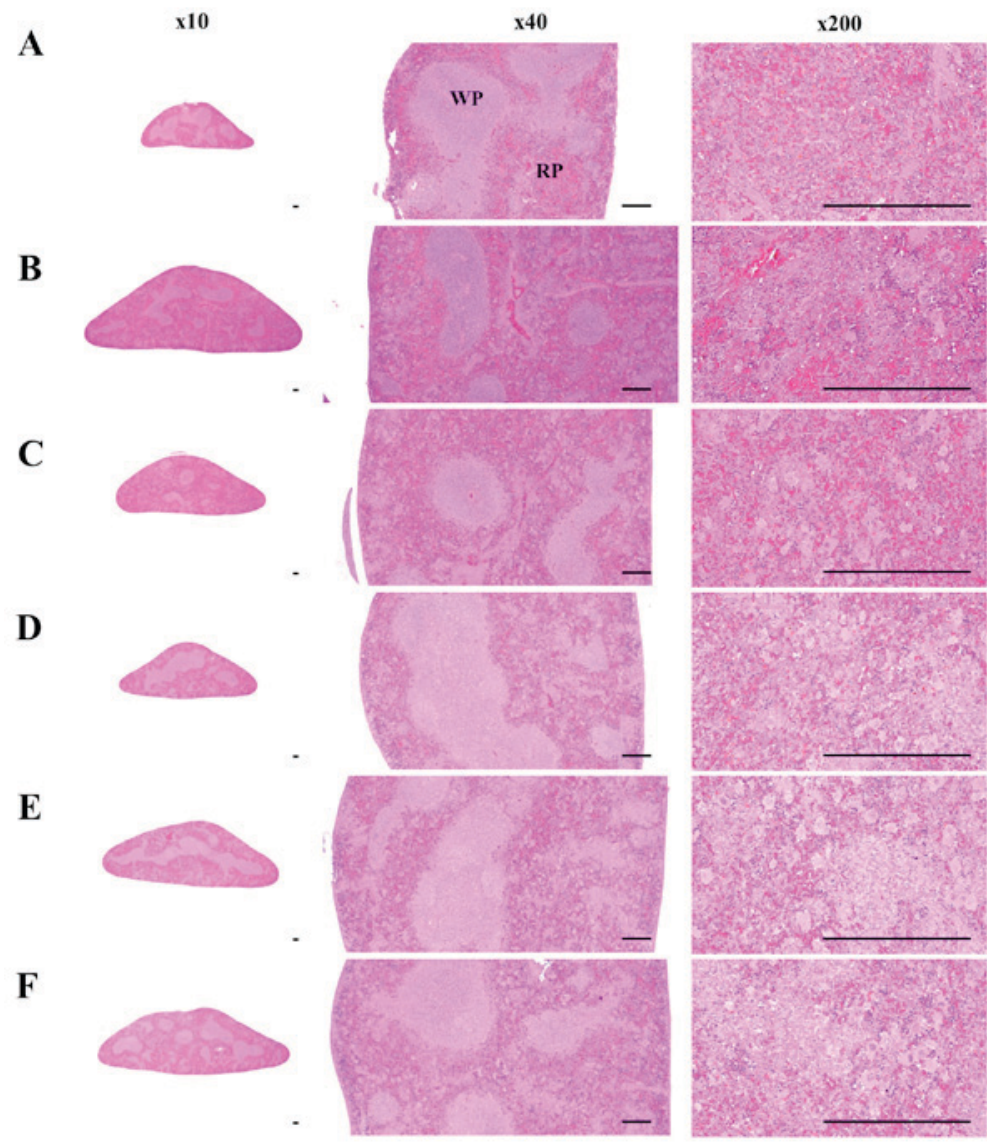

Figure 6. Representative histological images of splenic tissues taken from unexposed intact mice or mice with DNCB-induced AD following bathing in distilled water or ESGWc, or receiving topical application of DEXA. Histological images from (A) intact vehicle control mice bathing in distilled water, (B) DNCB control mice bathing in distilled water, (C) mice with DNCB-induced AD treated with topical application of $1 \%$ DEXA and mice with DNCB-induced AD following bathing in ESGWc at (D) 100-, (E) 200- and (F) 400-fold dilution. Scale bar, $200 \mu \mathrm{m}$. Stain, hematoxylin and eosin. AD, allergic/atopic-like dermatitis; DNCB, 2,4-dinitrochlorobenzene; DEXA, dexamethasone; ESGWc, east saline groundwater concentration solution (50X); WP, white pulp; RP, red pulp.

and differentiation of T cells into effector T cells (41). In addition, IL-2 serves an important role in the induction of pruritus in atopic dermatitis (42). IFN- $\gamma$ is produced by CD8+ T cells, Th1 cells and natural killer (NK) cells in response to IL-2. IFN- $\gamma$ stimulates NK cell and macrophage activities and also exerts various effects on B and T cells (43). Increases in IFN- $\gamma$ activities have also been detected in DNCB-induced dermatitis (44). iNOS is involved in the production of nitric oxide from L-arginine. High-output production of iNOS occurs under oxidative conditions. Excess levels of NO may increase the likelihood of interaction with superoxide, leading to peroxynitrite formation and cell toxicity (45). Pro-inflammatory agents, including endotoxin, IL- $1 \beta$, TNF- $\alpha$ and IFN- $\gamma$, may stimulate an increase in iNOS activity (46) and iNOS is also involved in the pathogenesis of atopic dermatitis (18). Therefore, the downregulation of iNOS, IL-2, TNF- $\alpha$ and IFN- $\gamma$ expression may have protective effects in various allergic diseases. In addition, $\mathrm{AD}$-induced systemic hypersensitivities induce marked proliferation of central and peripheral lymphocytes, particularly T cells $(18,31)$.

As a result, in the present study, depletion of endogenous antioxidant GSH and increases of superoxide anion were significantly inhibited by bathing in ESGWc dilution, which acted as an antioxidant. In addition, epidermal NT and 4-HNE immunoreactive cells were significantly inhibited by bathing in ESGWc dilutions. These findings suggest that bathing in ESGWc dilutions reduces DNCB-induced dermatitis symptoms through potent antioxidative effects. It has been reported that hydrotherapy has potent antioxidant effects on various forms of dermatitis $(15,18)$. Further supporting the antioxidant effects of bathing in ESGWc, previous research has demonstrated that bathing in ESGW inhibited lipid peroxidation, as determined by the MDA concentration of TBARS assay (18). Many toxic substances induce lipid peroxidation damage to the surrounding tissues (47) and AD also causes an imbalance between ROS production and endogenous antioxidant capacity, resulting in depletion of endogenous antioxidants, such as $\mathrm{GSH}$, an epidermal marker that is sensitive to oxidative stress (48). $\mathrm{GSH}$, an important endogenous antioxidant, protects against tissue damage by maintaining ROS at low levels and at certain cellular concentrations (49). The highly polarizable sulfhydryl group of GSH facilitates the scavenging of radicals directly by hydrogen transfer, making it an optimum nucleophile for reactions with electrophilic chemicals (23). Acting as a cofactor for GSH peroxidase and GSH reductase, it may remove hydrogen peroxide and lipid hydroperoxides (50).

The $\alpha, \beta$-unsaturated hydroxyalkenal $4-\mathrm{HNE}$, is generated as a result of lipid peroxidation and is a biomarker for oxidative stress (51). It is also regarded as a potential causal agent of various diseases, including chronic inflammation, 
Table XII. Splenic tissue histomorphometry after 6 weeks of bathing in ESGWc or topical application of DEXA in mice with DNCB-induced AD.

Controls

Bathing in ESGWc dilutions cells ${ }^{\mathrm{c}}$

\begin{tabular}{|c|c|c|c|c|c|c|}
\hline \multirow[b]{2}{*}{ Index } & & \multirow[b]{2}{*}{ DEXA } & & & \\
\hline & Intact & DNCB & & 100-fold & 200-fold & 400-fold \\
\hline $\begin{array}{l}\text { Total Th, } \mathrm{mm} / \\
\text { central regions }\end{array}$ & $1.46 \pm 0.29$ & $3.47 \pm 0.39^{\mathrm{d}}$ & $1.73 \pm 0.20^{\mathrm{e}}$ & $2.01 \pm 0.30^{\mathrm{d}, \mathrm{e}}$ & $2.24 \pm 0.28^{\mathrm{d}, \mathrm{e}}$ & $2.39 \pm 0.38^{\mathrm{d}, \mathrm{e}}$ \\
\hline White pulp ${ }^{\mathrm{a}}$ & $12.13 \pm 1.55$ & $13.50 \pm 2.56$ & $12.63 \pm 1.41$ & $12.00 \pm 1.77$ & $13.38 \pm 1.69$ & $13.63 \pm 2.26$ \\
\hline Red pulp ${ }^{\mathrm{b}}$ & $2.69 \pm 0.56$ & $34.30 \pm 10.11^{\mathrm{d}}$ & $4.98 \pm 1.33^{\mathrm{d}, \mathrm{e}}$ & $9.65 \pm 2.99^{\mathrm{d}, \mathrm{e}}$ & $16.15 \pm 2.82^{\mathrm{d}, e}$ & $22.29 \pm 5.10^{\mathrm{d}, \mathrm{e}}$ \\
\hline \multicolumn{7}{|l|}{$\begin{array}{l}\text { Immunoreactive } \\
\text { cells }{ }^{\mathrm{c}}\end{array}$} \\
\hline TNF- $\alpha$ & $15.38 \pm 2.00$ & $471.13 \pm 88.58^{\mathrm{d}}$ & $55.38 \pm 13.14^{\mathrm{d}, \mathrm{e}}$ & $127.00 \pm 24.17^{\mathrm{d}, \mathrm{e}}$ & $277.25 \pm 60.30^{\mathrm{d}, \mathrm{e}}$ & $334.38 \pm 65.07^{\mathrm{d}, \mathrm{e}}$ \\
\hline IFN- $\gamma$ & $61.38 \pm 14.05$ & $704.50 \pm 155.85^{\mathrm{d}}$ & $144.13 \pm 25.39^{\mathrm{d}, \mathrm{e}}$ & $301.88 \pm 40.13^{\mathrm{d}, \mathrm{e}}$ & $380.00 \pm 54.65^{\mathrm{de}}$ & $513.13 \pm 68.77^{\mathrm{d}, \mathrm{e}}$ \\
\hline iNOS & $64.00 \pm 15.09$ & $829.38 \pm 85.72^{\mathrm{d}}$ & $147.88 \pm 27.88^{\mathrm{d}, \mathrm{e}}$ & $356.25 \pm 100.05^{\mathrm{d}, \mathrm{e}}$ & $556.63 \pm 113.03^{\mathrm{d}, \mathrm{e}}$ & $640.50 \pm 115.92^{\mathrm{d}, \mathrm{e}}$ \\
\hline IL-1 $\beta$ & $143.38 \pm 25.16$ & $893.88 \pm 170.86^{\mathrm{d}}$ & $144.38 \pm 42.08^{\mathrm{e}}$ & $368.88 \pm 107.94^{\mathrm{d}, \mathrm{e}}$ & $471.13 \pm 140.56^{\mathrm{d}, \mathrm{e}}$ & $626.13 \pm 159.79^{\mathrm{d}, \mathrm{e}}$ \\
\hline IL-2 & $75.13 \pm 14.82$ & $878.00 \pm 134.90^{\mathrm{d}}$ & $150.63 \pm 25.40^{\mathrm{d}, \mathrm{e}}$ & $412.63 \pm 60.59^{\mathrm{d}, \mathrm{e}}$ & $538.00 \pm 141.18^{\mathrm{d}, \mathrm{e}}$ & $651.38 \pm 150.39^{\mathrm{d}, \mathrm{c}}$ \\
\hline
\end{tabular}

${ }^{a}$ Number of cells $/ \mathrm{mm}^{2}$ of splenic parenchyma; ${ }^{b} \times 10^{3}$ cells $/ \mathrm{mm}^{2}$ of splenic parenchyma; ${ }^{c}$ number of immunoreactive cells $/ \mathrm{mm}^{2}$ of splenic parenchyma; ${ }^{\mathrm{P}}<0.05$ vs. Intact control; ${ }^{\mathrm{e}} \mathrm{P}<0.05$ vs. $\mathrm{DNCB}$ control. Values are expressed as the mean \pm standard deviation $(\mathrm{n}=8)$. $\mathrm{AD}$, allergic/atopic-like dermatitis; DNCB, 2,4-dinitrochlorobenzene; DEXA, dexamethasone; ESGWc, east saline ground water concentration solution (50X); Th, thickness; IFN, interferon; IL, interleukin; iNOS, inducible nitric oxide synthase; TNF, tumor necrosis factor.

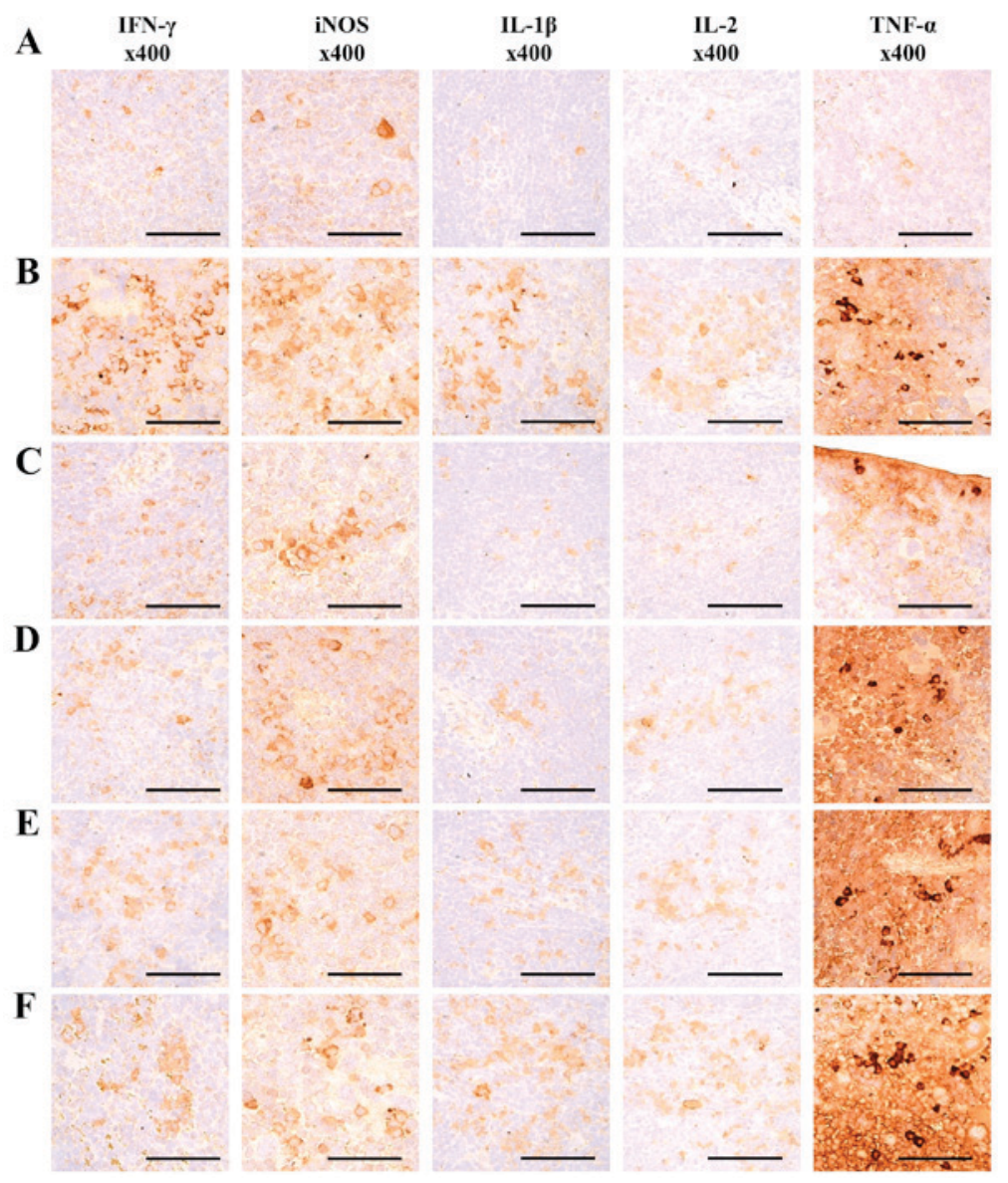

Figure 7. Representative immunohistochemical images of IFN- $\gamma$, iNOS, IL-1 $\beta$, IL-2 and TNF- $\alpha$ in the splenic tissues taken from unexposed intact mice or mice with DNCB-induced AD following bathing in distilled water or ESGWc, or receiving topical application of DEXA. Immunohistochemical images from (A) intact vehicle control mice bathing in distilled water, (B) DNCB control mice bathing in distilled water, (C) mice with DNCB-induced AD treated with topical application of 1\% DEXA and mice with DNCB-induced AD after bathing in ESGWc at (D) 100-, (E) 200- and (F) 400 -fold dilution. Scale bar, $40 \mu \mathrm{m}$. Stain, avidin-biotin complex immunostain. AD, allergic/atopic-like dermatitis; DNCB, 2,4-dinitrochlorobenzene; DEXA, dexamethasone; ESGWc, east saline groundwater concentration solution (50X); IFN, interferon; IL, interleukin; iNOS, inducible nitric oxide synthase; TNF, tumor necrosis factor. 


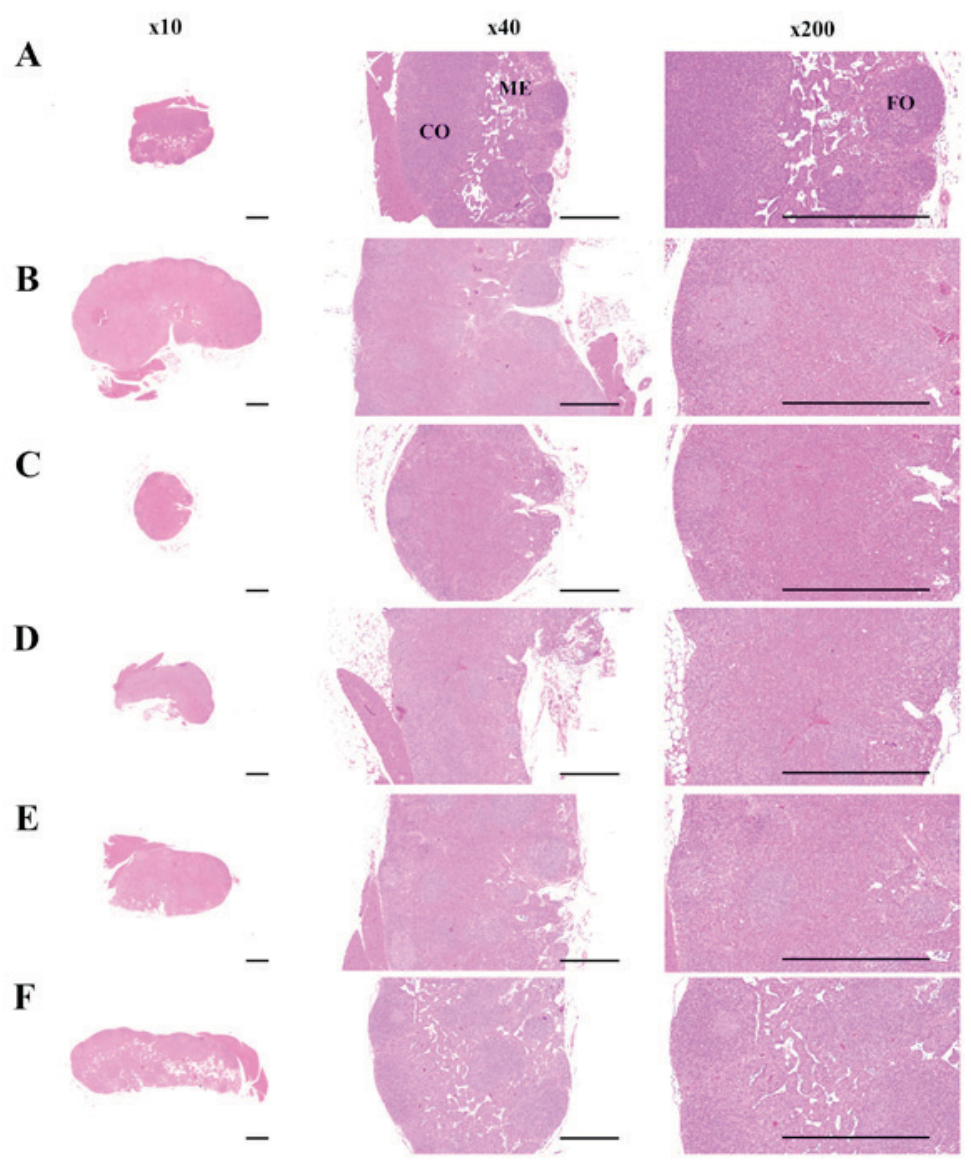

Figure 8. Representative histological images of submandibular LN tissues taken from unexposed intact mice or mice with DNCB-induced AD following bathing in distilled water or ESGWc, or receiving topical application of DEXA. Histological images from (A) intact vehicle control mice bathing in distilled water, (B) DNCB control mice bathing in distilled water, (C) mice with DNCB-induced AD treated with topical application of $1 \%$ DEXA and mice with DNCB-induced AD following bathing in ESGWc at (D) 100-, (E) 200- and (F) 400-fold dilution. Scale bar=400 $\mu$ m. Stain, hematoxylin and eosin. AD, allergic/atopic-like dermatitis; DNCB, 2,4-dinitrochlorobenzene; DEXA, dexamethasone; ESGWc, east saline groundwater concentration solution (50X); LN, lymph node; $\mathrm{CO}$, cortex; FO, lymphoid follicle; ME, medulla.

neurodegenerative disease, adult respiratory distress syndrome, atherogenesis, diabetes and various types of cancer (51). NT is a product of tyrosine nitration mediated by reactive nitrogen species, including peroxynitrite anion and nitrogen dioxide. It is accepted as a marker of iNOS-dependent, reactive nitrogen species-induced nitrative stress in many pathological conditions $(52,53)$.

To examine the cytoprotective anti-apoptotic effects of bathing in ESGWc dilutions in the present study, the activities of caspase-3 and PARP were examined in mice with DNCB-induced AD. Bathing in ESGWc dilutions exerted potent keratinocyte protection activity against DNCB-induced epidermal apoptosis by modulating the activities of caspase-3 and PARP. It has been demonstrated that the cleavage of PARP is accompanied by a decrease in enzymatic repair function and consequently leads to the progression of apoptosis (54). Caspase-3 contributes to the cleavage of key nuclear targets in the apoptotic pathway. It contains the inhibitor of caspase-activated deoxynuclease, which causes nuclear fragmentation and PARP cleavage, consequently leading to a decrease in DNA repair (55). Thus, caspase- 3 is considered to be an important executioner of apoptosis, as it is involved in the proteolytic cleavage of pivotal proteins, such as PARP (56). PARP is a recognized target molecule of caspase-3, which induces the activation of the DNA repair system by caspase-mediated cleavage (57). However, previous studies have reported that overexpression of PARP proteins induced necrosis as intracellular energy levels were decreased through the over-consumption of its substrate, nicotinamide adenine dinucleotide (58-60). Although the association of PARP with apoptosis and necrosis remains unclear, the suppression of PARP is regarded as a useful strategy for protecting against various forms of skin damage (61) induced by apoptotic changes in DNCB-induced allergic dermatitis $(18,30)$

As MMPs are able to degrade various extracellular matrix components and are known to serve important roles in tissue remodeling during developmental morphogenesis, angiogenesis, tissue repair, arthritis, skin aging and tumor invasion (62), the present study examined whether regulation of MMP activity by bathing in ESGWc was involved in DNCB-induced skin sclerosis. The results indicated that bathing in ESGWc (up to 400-fold dilution) exerted strong inhibitory activity against DNCB-induced skin sclerosis by modulating the activities of MMP-9. MMPs, a family of structurally related endopeptidases (63) are categorized into collagenases, gelatinases, stromelysins, membrane-type MMPs and other MMPs, according to their structures and substrate specificities (64). 
Table XIII. Submandibular LN tissue histomorphometry after 6 weeks of bathing in ESGWc or topical application of DEXA in mice with DNCB-induced AD.

\begin{tabular}{|c|c|c|c|c|c|c|}
\hline \multirow[b]{2}{*}{ Index } & \multicolumn{2}{|c|}{ Controls } & \multirow[b]{2}{*}{ DEXA } & \multicolumn{3}{|c|}{ Bathing in ESGWc dilutions } \\
\hline & Intact & DNCB & & 100-fold & 200-fold & 400-fold \\
\hline $\begin{array}{l}\text { Total Th, } \mathrm{mm} / \\
\text { central regions }\end{array}$ & $0.73 \pm 0.13$ & $1.89 \pm 0.23^{\mathrm{d}}$ & $1.02 \pm 0.17^{\mathrm{d}, \mathrm{e}}$ & $1.13 \pm 0.19^{\mathrm{d}, \mathrm{e}}$ & $1.21 \pm 0.15^{\mathrm{d}, \mathrm{e}}$ & $1.39 \pm 0.13^{\mathrm{d}, \mathrm{e}}$ \\
\hline Follicles $^{\mathrm{a}}$ & $12.50 \pm 1.93$ & $35.00 \pm 5.40^{\mathrm{d}}$ & $16.00 \pm 2.45^{\mathrm{d}, \mathrm{e}}$ & $17.88 \pm 2.75^{\mathrm{d}, \mathrm{e}}$ & $19.63 \pm 2.97^{\mathrm{d}, \mathrm{e}}$ & $26.25 \pm 6.30^{\mathrm{d}, \mathrm{e}}$ \\
\hline Cortex $\mathrm{Th}^{\mathrm{b}}$ & $364.96 \pm 112.92$ & $987.27 \pm 146.47^{\mathrm{d}}$ & $431.98 \pm 86.57^{\mathrm{e}}$ & $566.65 \pm 143.70^{\mathrm{d}, \mathrm{e}}$ & $759.54 \pm 109.37^{\mathrm{d}, \mathrm{e}}$ & $804.96 \pm 92.38^{\mathrm{d}, \mathrm{e}}$ \\
\hline \multicolumn{7}{|l|}{$\begin{array}{l}\text { Immunoreactive } \\
\text { cells }^{\mathrm{c}}\end{array}$} \\
\hline TNF- $\alpha$ & $7.23 \pm 1.26$ & $139.63 \pm 34.18^{\mathrm{d}}$ & $23.23 \pm 8.57^{\mathrm{d}, \mathrm{e}}$ & $34.21 \pm 9.08^{\mathrm{d}, \mathrm{e}}$ & $46.71 \pm 12.43^{\mathrm{d}, \mathrm{e}}$ & $75.45 \pm 21.96^{\mathrm{d}, \mathrm{e}}$ \\
\hline $\mathrm{IFN}-\gamma$ & $9.31 \pm 2.37$ & $217.28 \pm 23.00^{\mathrm{d}}$ & $21.20 \pm 7.38^{\mathrm{d}, \mathrm{e}}$ & $74.94 \pm 21.86^{\mathrm{d}, \mathrm{e}}$ & $119.58 \pm 26.28^{\mathrm{d}, \mathrm{e}}$ & $177.78 \pm 22.73^{\mathrm{d}, \mathrm{e}}$ \\
\hline iNOS & $9.39 \pm 3.04$ & $167.09 \pm 31.30^{\mathrm{d}}$ & $21.43 \pm 8.37^{\mathrm{d}, \mathrm{e}}$ & $42.69 \pm 15.02^{\mathrm{d}, \mathrm{e}}$ & $55.13 \pm 12.98^{\mathrm{d}, \mathrm{e}}$ & $63.11 \pm 12.43^{\mathrm{d}, \mathrm{e}}$ \\
\hline IL-1 $\beta$ & $14.11 \pm 3.65$ & $135.53 \pm 21.48^{\mathrm{d}}$ & $49.26 \pm 13.39^{\mathrm{d}, \mathrm{e}}$ & $54.50 \pm 15.18^{\mathrm{d}, \mathrm{e}}$ & $72.50 \pm 10.25^{\mathrm{d}, \mathrm{e}}$ & $99.44 \pm 15.76^{\mathrm{d}, \mathrm{e}}$ \\
\hline IL-2 & $3.24 \pm 1.35$ & $89.48 \pm 12.43^{\mathrm{d}}$ & $19.19 \pm 7.30^{\mathrm{d}, \mathrm{e}}$ & $26.16 \pm 11.27^{\mathrm{d}, \mathrm{e}}$ & $39.79 \pm 11.69^{\mathrm{d}, \mathrm{e}}$ & $48.91 \pm 18.70^{\mathrm{d}, \mathrm{e}}$ \\
\hline
\end{tabular}

${ }^{\mathrm{a} N u m b e r s} / \mathrm{mm}^{2}$ of cortex; ${ }^{\mathrm{b}} \mu \mathrm{m} / \mathrm{LN} ;{ }^{\mathrm{c}} \mathrm{x} 10$ cells $/ \mathrm{mm}^{2}$ of $\mathrm{LN}$ parenchyma; ${ }^{\mathrm{d}} \mathrm{P}<0.05$ vs. Intact control; ${ }^{\mathrm{e}} \mathrm{P}<0.05$ vs. DNCB control. Values are expressed as the mean \pm standard deviation $(n=8)$. LN, lymph node; AD, allergic/atopic-like dermatitis; DNCB, 2,4-dinitrochlorobenzene; DEXA, dexamethasone; ESGWc, east saline ground water concentration solution (50X); Th, thickness; IFN, interferon; IL, interleukin; iNOS, inducible nitric oxide synthase; TNF, tumor necrosis factor.

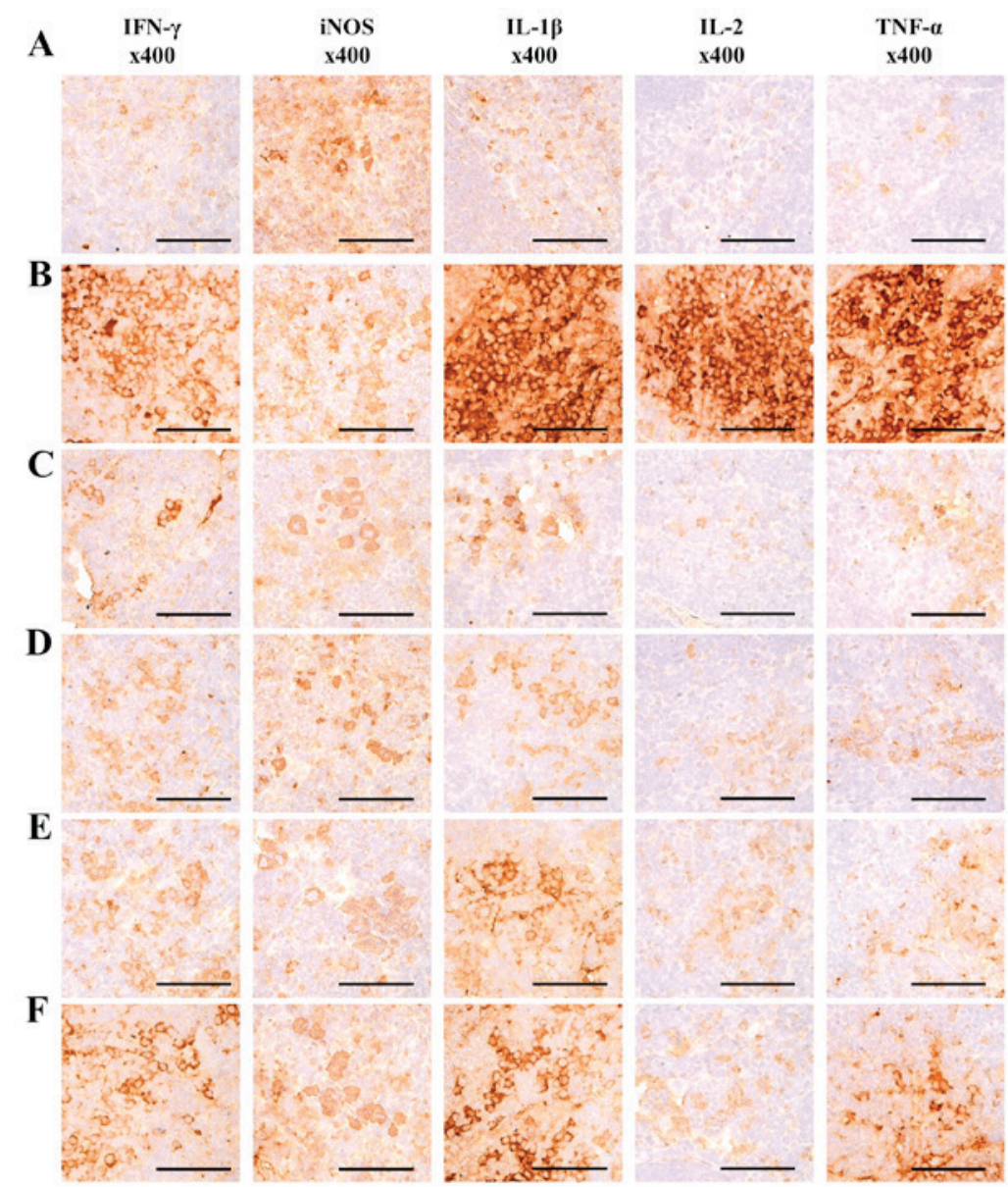

Figure 9. Representative immunohistochemical images of IFN- $\gamma$, iNOS, IL-1 $\beta$, IL-2 and TNF- $\alpha$ in the submandibular LN tissues taken from unexposed intact mice or mice with DNCB-induced AD following bathing in distilled water or ESGWc, or receiving topical application of DEXA. Immunohistochemical images from (A) intact vehicle control mice bathing in distilled water, (B) DNCB control mice bathing in distilled water, (C) mice with DNCB-induced AD treated with topical application of 1\% DEXA and mice with DNCB-induced AD after bathing in ESGWc at (D) 100-, (E) 200- and (F) $400-$ fold dilution. Scale bar=40 $\mu$ m. Stain, avidin-biotin complex immunostain. AD, allergic/atopic-like dermatitis; DNCB, 2,4-dinitrochlorobenzene; DEXA, dexamethasone; ESGWc, east saline groundwater concentration solution (50X); IFN, interferon; IL, interleukin; iNOS, inducible nitric oxide synthase; TNF, tumor necrosis factor. 
Levels of MMPs are usually low in unstimulated skin tissues and levels are upregulated following exposure to various extracellular stimuli, including ultraviolet light, growth factors, cytokines and tumor promoters $(64,65)$. Previous studies have indicated that there was a significant increase in a number of MMPs, particularly MMP-8 and MMP-9, in AD patients $(66,67)$. Such research suggests that reducing MMP activity may be a protective approach to attenuate AD-related skin sclerosis $(18,68)$.

The results obtained in the present study suggest that bathing in all three concentrations (100-, 200- and 400-fold dilutions) of ESGWc have favorable protective effects against DNCB-induced AD. It was demonstrated that ESGWc has favorable systemic and local immunomodulatory effects, active cytoprotective anti-apoptotic effects, inhibitory effects of MMP activity, anti-inflammatory and antioxidative effects, in a concentration-dependent manner. In conclusion, bathing in ESGWc, may provide an alternative therapy for patients with AD in the future, at least under the conditions of this experiment. Topical application of 1\% DEXA also significantly inhibited the DNCB-induced AD; however, it did not influence dermal collagen depositions and skin tissue antioxidant defense systems in the present experiment.

\section{Acknowledgements}

The present study was supported by the Republic of Korea Institute of Ocean Science and Technology (grant no. PE99365) and the National Research Foundation of Korea grant funded by the Korea government (grant no. 2012R1A5A2A42671316).

\section{References}

1. Leung DY: Atopic dermatitis: New insights and opportunities for therapeutic intervention. J Allergy Clin Immunol 105: 860-876, 2000.

2. Thestrup-Pedersen $\mathrm{K}$ : Clinical aspects of atopic dermatitis. Clin Exp Dermatol 25: 535-543, 2000.

3. Park G and Oh MS: Inhibitory effects of Juglans mandshurica leaf on allergic dermatitis-like skin lesions-induced by 2,4-dinitrochlorobenzene in mice. Exp Toxicol Pathol 66 97-101, 2014

4. Saeki H, Furue M, Furukawa F, Hide M, Ohtsuki M, Katayama I, Sasaki R, Suto H and Takehara K; Committee for guidelines for the management of atopic dermatitis of japanese dermatological association: Guidelines for management of atopic dermatitis. J Dermatol 36: 563-577, 2009.

5. Pugliarello S, Cozzi A, Gisondi P and Girolomoni G: Phenotypes of atopic dermatitis. J Dtsch Dermatol Ges 9: 12-20, 2011 (In English; In German).

6. Kim SR, Choi HS, Seo HS, Choi YK, Shin YC and Ko SG: Topical application of herbal mixture extract inhibits ovalbuminor 2,4-dinitrochlorobenzene-induced atopic dermatitis. Evid Based Complement Alternat Med 2012: 545497, 2012.

7. Koga C, Kabashima K, Shiraishi N, Kobayashi M and Tokura Y: Possible pathogenic role of Th17 cells for atopic dermatitis. J Invest Dermatol 128: 2625-2630, 2008.

8. Okayama Y: Oxidative stress in allergic and inflammatory skin diseases. Curr Drug Targets Inflamm Allergy 4: 517-519, 2005.

9. Tasaka K: Anti-allergic drugs. Drugs of today 22: 101-133, 1986.

10. Merial-Kieny C, Mengual X, Guerrero D and Sibaud V: Clinical efficacy of Avène hydrotherapy measured in a large cohort of more than 10,000 atopic or psoriatic patients. J Eur Acad Dermatol Venereol 25 (Suppl 1): S30-S34, 2011.

11. Brockow T, Schiener R, Franke A, Resch KL and Peter RU: A pragmatic randomized controlled trial on the effectiveness of low concentrated saline spa water baths followed by ultraviolet B (UVB) compared to UVB only in moderate to severe psoriasis. J Eur Acad Dermatol Venereol 21: 1027-1037, 2007.
12. Peroni A, Gisondi P, Zanoni M and Girolomoni G: Balneotherapy for chronic plaque psoriasis at Comano spa in Trentino, Italy. Dermatol Ther 21 (Suppl 1): S31-S38, 2008.

13. Portalès P, Ariès MF, Licu D, Pinton J, Hernandez-Pion C, Gall Y, Dupuy P, Charveron M and Clot J: Immunomodulation induced by Avène spring water on Th1- and Th2-dependent cytokine production in healthy subjects and atopic dermatitis patients. Skin Pharmacol Appl Skin Physiol 14: 234-242, 2001.

14. Fioravanti A, Lamboglia A,Pascarelli NA, Cheleschi S, Manica P Galeazzi M and Collodel G: Thermal water of Vetriolo, Trentino, inhibits the negative effect of interleukin-1b; on nitric oxide production and apoptosis in human osteoarthritic chondrocyte. J Biol Regul Homeost Agents 27: 891-902, 2013.

15. Prandelli C, Parola C, Buizza L, Delbarba A, Marziano M, Salvi V,Zacchi V, Memo M, Sozzani S, Calza S, et al: Sulphurous thermal water increases the release of the anti-inflammatory cytokine IL-10 and modulates antioxidant enzyme activity. Int J Immunopathol Pharmacol 26: 633-646, 2013

16. Adler-Cohen C, Czarnowicki T, Dreiher J, Ruzicka T, Ingber A and Harari M: Climatotherapy at the Dead Sea: An effective treatment modality for atopic dermatitis with significant positive impact on quality of life. Dermatitis 23: 75-80, 2012.

17. Bak JP, Kim YM, Son J, Kim CJ and Kim EH: Application of concentrated deep sea water inhibits the development of atopic dermatitis-like skin lesions in NC/Nga mice. BMC Complement Altern Med 12: 108, 2012.

18. Kim CG, Kang M, Lee YH, Min WG, Kim YH, Kang SJ, Song $\mathrm{CH}$, Park SJ, Park JH, Han CH, et al: Bathing effects of various seawaters on allergic (Atopic) dermatitis-like skin lesions induced by 2,4-dinitrochlorobenzene in hairless mice. Evid Based Complement Alternat Med 2015: 179185, 2015.

19. Matsumoto K, Mizukoshi K, Oyobikawa M, Ohshima H and Tagami H: Establishment of an atopic dermatitis-like skin model in a hairless mouse by repeated elicitation of contact hypersensitivity that enables to conduct functional analyses of the stratum corneum with various non-invasive biophysical instruments. Skin Res Technol 10: 122-129, 2004.

20. Park MS, Chang BS and Kim DH: The bathing effect of mineral-rich water on atopic dermatitis like skin lesions in hairless mice. J Invest Cosmet 7: 181-187, 2011.

21. Clark BD, Bedrosian I, Schindler R, Cominelli F, Cannon JG, Shaw AR and Dinarello CA: Detection of interleukin 1 alpha and 1 beta in rabbit tissues during endotoxemia using sensitive radioimmunoassays. J Appl Physiol (1985) 71: 2412-2418, 1991.

22. Livak KJ and Schmittgen TD: Analysis of relative gene expression data using real-time quantitative PCR and the 2(-Delta Delta C(T)) method. Methods 25: 402-408, 2001.

23. Campanini MZ, Pinho-Ribeiro FA, Ivan AL, Ferreira VS, Vilela FM, Vicentini FT, Martinez RM, Zarpelon AC, Fonseca MJ, Faria TJ, et al: Efficacy of topical formulations containing Pimenta pseudocaryophyllus extract against UVB-induced oxidative stress and inflammation in hairless mice. J Photochem Photobiol B 127: 153-160, 2013.

24. Lowry OH, Rosebrough NJ, Farr AL and Randall RJ: Protein measurement with the Folin phenol reagent. J Biol Chem 193: 265-275, 1951.

25. Jamall IS and Smith JC: Effects of cadmium on glutathione peroxidase, superoxide dismutase and lipid peroxidation in the rat heart: A possible mechanism of cadmium cardiotoxicity. Toxicol Appl Pharmacol 80: 33-42, 1985.

26. Harrigan TJ, Abdullaev IF, Jourd'heuil D and Mongin AA: Activation of microglia with zymosan promotes excitatory amino acid release via volume-regulated anion channels: The role of NADPH oxidases. J Neurochem 106: 2449-2462, 2008.

27. Kim KH, Park SJ, Lee YJ, Lee JE, Song CH, Choi SH, Ku SK and Kang SJ: Inhibition of UVB-induced skin damage by exopolymers from Aureobasidium pullulans SM-2001 in hairless mice. Basic Clin Pharmacol Toxicol 116: 73-86, 2015.

28. Kang SJ, Lee JE, Lee EK, Jung DH, Song CH, Park SJ, Choi SH, Han CH, Ku SK and Lee YJ: Fermentation with Aquilariae Lignum enhances the anti-diabetic activity of green tea in type II diabetic db/db mouse. Nutrients 6: 3536-3571, 2014.

29. Li C, Lasse S, Lee P, Nakasaki M, Chen SW, Yamasaki K Gallo RL and Jamora C: Development of atopic dermatitis-like skin disease from the chronic loss of epidermal caspase-8. Proc Natl Acad Sci USA 107: 22249-22254, 2010.

30. Nadworny PL, Wang J, Tredget EE and Burrell RE: Anti-inflammatory activity of nanocrystalline silver in a porcine contact dermatitis model. Nanomedicine 4: 241-251, 2008. 
31. Lee JK, Park JH, Park SH, Kim HS and Oh HY: A nonradioisotopic endpoint for measurement of lymph node cell proliferation in a murine allergic contact dermatitis model, using bromodeoxyuridine immunohistochemistry. J Pharmacol Toxicol Methods 48: 53-61, 2002.

32. Choi JH, Kim HG, Jin SW, Han EH, Khanal T, Do MT, Hwang YP, Choi JM, Chun SS, Chung YC, et al: Topical application of Pleurotus eryngii extracts inhibits 2,4-dinitrochlorobenzene-induced atopic dermatitis in NC/Nga mice by the regulation of Th1/Th2 balance. Food Chem Toxicol 53: 38-45, 2013.

33. Sawada E, Yoshida N, Sugiura A and Imokawa G: Th1 cytokines accentuate but $\mathrm{Th} 2$ cytokines attenuate ceramide production in the stratum corneum of human epidermal equivalents: An implication for the disrupted barrier mechanism in atopic dermatitis. J Dermatol Sci 68: 25-35, 2012.

34. Vestergaard C, Yoneyama H, Murai M, Nakamura K, Tamaki K, Terashima Y, Imai T, Yoshie O, Irimura T, Mizutani H and Matsushima K: Overproduction of Th2-specific chemokines in $\mathrm{NC} / \mathrm{Nga}$ mice exhibiting atopic dermatitis-like lesions. J Clin Invest 104: 1097-1105, 1999.

35. Poulsen LK and Hummelshoj L: Triggers of IgE class switching and allergy development. Ann Med 39: 440-456, 2007.

36. Yamanaka $\mathrm{K}$ and Mizutani $\mathrm{H}$ : The role of cytokines/chemokines in the pathogenesis of atopic dermatitis. Curr Probl Dermatol 41 80-92, 2011.

37. Beutler B, Greenwald D, Hulmes JD, Chang M, Pan YC, Mathison J, Ulevitch R and Cerami A: Identity of tumour necrosis factor and the macrophage-secreted factor cachectin. Nature 316: 552-554, 1985.

38. Whittle BJ, Varga C, Berko A, Horvath K, Posa A, Riley JP, Lundeen KA, Fourie AM and Dunford PJ: Attenuation of inflammation and cytokine production in rat colitis by a novel selective inhibitor of leukotriene A4 hydrolase. Br J Pharmacol 153 983-991, 2008

39. Schottelius AJ, Zügel U, Döcke WD, Zollner TM, Röse L, Mengel A, Buchmann B, Becker A, Grütz G, Naundorf S, et al: The role of mitogen-activated protein kinase-activated protein kinase 2 in the p38/TNF-alpha pathway of systemic and cutaneous inflammation. J Invest Dermatol 130: 481-491, 2010

40. Assuma R, Oates T, Cochran D, Amar S and Graves DT: IL-1 and TNF antagonists inhibit the inflammatory response and bone loss in experimental periodontitis. J Immunol 160: 403-409, 1998.

41. Smith KA: Interleukin-2: Inception, impact, and implications Science 240: 1169-1176, 1988

42. Fallahzadeh MK, Roozbeh J, Geramizadeh B and Namazi MR Interleukin-2 serum levels are elevated in patients with uremic pruritus: A novel finding with practical implications. Nephrol Dial Transplant 26: 3338-3344, 2011.

43. Isaacs A: Lymphokines and Cytokines. In: Immunology, an Introduction. Tizard IR (eds). Saunders College Pub., Philadelphia, pp155-169, 1995.

44. Ku HO, Jeong SH, Kang HG, Pyo HM, Cho JH, Son SW, Kim HR, Lee KJ and Ryu DY: Intracellular expression of cytokines and granzyme B in auricular lymph nodes draining skin exposed to irritants and sensitizers. Toxicology 250: 116-123, 2008

45. Mungrue IN, Husain M and Stewart DJ: The role of NOS in heart failure: Lessons from murine genetic models. Heart Fail Rev 7 : 407-422, 2002.

46. Szabó C: Alterations in nitric oxide production in various forms of circulatory shock. New Horiz 3: 2-32, 1995.

47. Comporti M: Lipid peroxidation and cellular damage in toxic liver injury. Lab Invest 53: 599-623, 1985.

48. Sivaranjani N, Rao SV and Rajeev G: Role of reactive oxygen species and antioxidants in atopic dermatitis. J Clin Diagn Res 7: 2683-2685, 2013

49. Odabasoglu F, Cakir A, Suleyman H, Aslan A, Bayir Y, Halici M and Kazaz C: Gastroprotective and antioxidant effects of usnic acid on indomethacin-induced gastric ulcer in rats. J Ethnopharmacol 103: 59-65, 2006.
50. Pinnell SR: Cutaneous photodamage, oxidative stress, and topical antioxidant protection. J Am Acad Dermatol 48: 1-19, 2003.

51. Dubinina EE and Dadali VA: Role of 4-hydroxy-trans-2-nonenal in cell functions. Biochemistry (Mosc) 75: 1069-1087, 2010.

52. Mohiuddin I, Chai H, Lin PH, Lumsden AB, Yao Q and Chen C: Nitrotyrosine and chlorotyrosine: Clinical significance and biological functions in the vascular system. J Surg Res 133: 143-149, 2006

53. Pacher P, Beckman JS and Liaudet L: Nitric oxide and peroxynitrite in health and disease. Physiol Rev 87: 315-424, 2007

54. Smulson ME, Pang D, Jung M, Dimtchev A, Chasovskikh S, Spoonde A, Simbulan-Rosenthal C, Rosenthal D, Yakovlev A and Dritschilo A: Irreversible binding of poly(ADP)ribose polymerase cleavage product to DNA ends revealed by atomic force microscopy: Possible role in apoptosis. Cancer Res 58: 3495-3498, 1998.

55. Smyth PG and Berman SA: Markers of apoptosis: Methods for elucidating the mechanism of apoptotic cell death from the nervous system. Biotechniques 32: 648-650, 652, 654 passim, 2002.

56. Fernandes-Alnemri T, Litwack G and Alnemri ES: CPP32, a novel human apoptotic protein with homology to Caenorhabditis elegans cell death protein Ced-3 and mammalian interleukin-1b-converting enzyme. J Biol Chem 269: 30761-30764, 1994.

57. Tewari M, QuanLT,O'RourkeK,Desnoyers S,Zeng Z,Beidler DR, Poirier GG, Salvesen GS and Dixit VM: Yama/CPP32b, a mammalian homolog of CED-3, is a CrmA-inhibitable protease that cleaves the death substrate poly(ADP-ribose) polymerase. Cell 81: 801-809, 1995.

58. Li H, Li Q, Li W, Xie L, Zhou M and Xie J: The role of PARP-1 in host pathogen interaction and cellular stress responses. Crit Rev Eukaryot Gene Expr 25: 175-190, 2015.

59. Virag L: Structure and function of poly(ADP-ribose) polymerase-1: Role in oxidative stress-related pathologues. Curr Vasc Pharmacol 3: 209-214, 2005.

60. Kauppinen TM, Gan L and Swanson RA: Poly(ADP-ribose) polymerase-1-induced NAD $(+)$ depletion promotes nuclear factor- $\kappa \beta$ trascriptional activity by preventing p 65 de-acetylation. Biochim Biophys Acta 1833: 1985-1991, 2013.

61. Cole KK and Perez-Polo JR: Poly(ADP-ribose) polymerase inhibition prevents both apoptotic-like delayed neuronal death and necrosis after $\mathrm{H}(2) \mathrm{O}(2)$ injury. J Neurochem 82: 19-29, 2002.

62. Kähäri VM and Saarialho-Kere U: Matrix metalloproteinases in skin. Exp Dermatol 6: 199-213, 1997.

63. Jin XJ, Kim EJ, Oh IK, Kim YK, Park CH and Chung JH: Prevention of UV-induced skin damages by $11,14,17$-eicosatrienoic acid in hairless mice in vivo. J Korean Med Sci 25: 930-937, 2010.

64. Nagase H and Woessner JF Jr: Matrix metalloproteinases. J Biol Chem 274: 21491-21494, 1999.

65. Rittie L and Fisher GJ: UV-light-induced signal cascades and skin aging. Ageing Res Rev 1: 705-720, 2002.

66. Devillers AC, van Toorenenbergen AW, Klein Heerenbrink GJ, Muldert PG and Oranje AP: Elevated levels of plasma matrix metalloproteinase-9 in patients with atopic dermatitis: a pilot study. Clin Exp Dermatol 32: 311-313, 2007.

67. Lü ZR, Park D, Lee KA, Ryu JW, Bhak J, Shi L, Lee DY, Park YD, Zou F and Yang JM: Profiling the dysregulated genes of keratinocytes in atopic dermatitis patients: cDNA microarray and interactomic analyses. J Dermatol Sci 54: 126-129, 2009.

68. Harper JI, Godwin H, Green A, Wilkes LE, Holden NJ, Moffatt M, Cookson WO, Layton G and Chandler S: A study of matrix metalloproteinase expression and activity in atopic dermatitis using a novel skin wash sampling assay for functional biomarker analysis. Br J Dermatol 162: 397-403, 2010. 